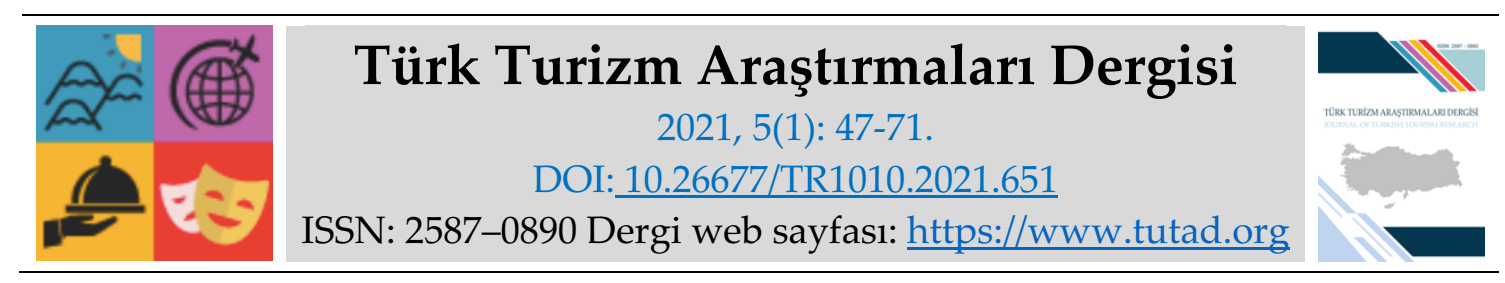

ARAȘTIRMA MAKALESI

\title{
Elazı̆̆ Mutfak Kültüründe Yer Alan Yöresel Yemeklerin İncelenmesi: Nitel Bir Araştırma
}

Öğr. Gör. Mustafa Oğuzhan ERCAN, İstanbul Rumeli Üniversitesi, Meslek Yüksekokulu, İstanbul, e-posta: moguzhan.ercan@rumeli.edu.tr ORCID: https://orcid.org/0000-0001-5498-0591

Dilek GÜLCAN, Yüksek Lisans Öğrencisi, Nevşehir Hacı Bektaş Veli Üniversitesi, Sosyal Bilimler Enstitüsü, Nevşehir, e-posta: dilekgulcan20@gmail.com

ORCID: https://orcid.org/0000-0003-0041-3246

\section{$\ddot{O} z$}

Bu çalışmanın amacı Elazığ mutfak kültüründe yer alan yöresel yemeklerin incelenmesidir. Bu amaç doğrultusunda araştırma yöntemi olarak nitel araştırma yöntemleri kapsamında görüşme tekniği ve ikincil verilerden yararlanılmıştır. Araştırma evrenini Elazı̆̆ Merkez ilçesinde yaşayan ev hanımları oluşturmaktadır. Örneklemi ise Elazı ğ' da doğmuş ve hâlen burada ikamet eden 40 yaş ve üzeri 13 ev hanımı oluşturmaktadır. Görüşmeler 15.12.2020-02.01.2021 tarihleri aralığında gerçekleştirilmiştir. Yapılan görüşmeler ve ikincil kaynaklardan elde edilen bulgular neticesinde 43 yemek, 12 çorba, 16 hamur işi, 12 tatlı ve içecek türü tespit edilmiştir. Yöre mutfağına ait yemeklerin turist beklentilerini karşılayacak çeşitliliğe sahip olduğu sonucuna ulaşılmıştır.

Anahtar Kelimeler: Elazığ, Gastronomi Turizmi, Yöresel Yemekler.

Makale Gönderme Tarihi: 21.01.2021

Makale Kabul Tarihi: 12.03 .2021

\section{Önerilen Atıf:}

Ercan, M. O. ve Gülcan, D. (2021). Elazı̆̆ Mutfak Kültüründe Yer Alan Yöresel Yemeklerin İncelenmesi: Nitel Bir Araştırma, Türk Turizm Araştırmaları Dergisi, 5(1): 47-71.

(C) 2021 Türk Turizm Araştırmaları Dergisi. 


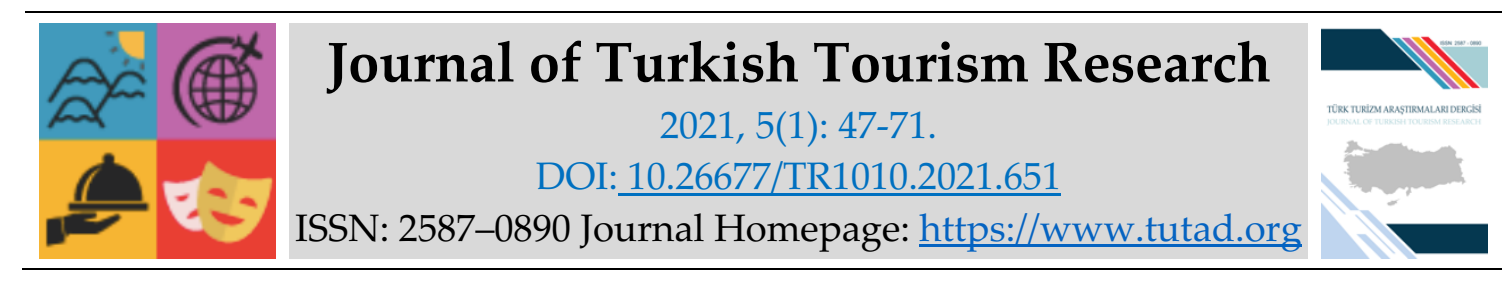

\title{
$\underline{\text { RESEARCH PAPER }}$
}

\section{Examination of Local Food in Elazı̆̆ Culinary Culture: A Qualitative Research}

Lecturer Mustafa Oğuzhan ERCAN, İstanbul Rumeli University, Vocational School, İstanbul, email: moguzhan.ercan@rumeli.edu.tr ORCID: https://orcid.org/0000-0001-5498-0591

Dilek GÜLCAN, MSc. Student, Nevşehir Hacı Bektaş Veli University, Social Sciences Institute, Nevşehir, e-mail: dilekgulcan20@gmail.com

ORCID: https://orcid.org/0000-0003-0041-3246

\begin{abstract}
The aim of this study is to evaluate the local food of Elazıg cuisine within the scope of gastronomy tourism. For this purpose, interview technique and secondary data were used as a research method within the scope of qualitative research methods. The research population consist of housewives living in Elazığ Central district. The sample consist of 13 housewives aged 40 and over, born and raised in Elazığ. The interviews were held between 15.12.2020-02.01.2021. A result of the interviews and findings obtained from secondary sources, 42 meals, 12 soups, 16 pastries, 12 dessert and beverage types were determined. It was concluded that the food of the local cuisine has a variety to meet the tourist expectations.
\end{abstract}

Keywords: Elazı $\breve{g}$, Gastronomy Tourism, Local Foods.

Received: 21.01.2021

Accepted: 12.03 .2021

\section{Suggested Citation:}

Ercan, M. O. and Gülcan, D. (2021). Examination of Local Food in Elazig Culinary Culture: A Qualitative Research, Journal of Turkish Tourism Research, 5(1): 47-71.

(C) 2021 Türk Turizm Araştırmaları Dergisi. 


\section{Gíriş}

Günümüzde turizm sektörünün hızlı bir şekilde değişime uğraması, sektördeki ürün arzının ve turistik destinasyonların farklılaşmasından dolayı çekicilik unsuru olabilecek alternatif turizm türlerine karşı beklentinin artmasına neden olmaktadır (Lordkipanidze, Brezet ve Backman, 2005). Sektör temsilcileri 1980'lerden günümüze kadar olan süreçte kitle turizmini, sektörün ekonomik olarak payının arttırılması ve turist beklentilerini karşılamak amacıyla turizmi 12 ay boyunca uygulamaya çalışmakta ve alternatif turizm ürünlerini turistlerin hizmetine sunmaktadır (İlban ve Yıldız, 2020:241). Turizmde sürdürülebilirliğin sağlanması adına farklı alternatifler mevcuttur. Bölgelerin destinasyon ölçeğinde pazarlanması ve özel ilgi turizmi kapsamında gerçekleştirilen turizm faaliyetleri ülkeler için önemli bir husustur (Aksoy ve Sezgi, 2015:80).

Turistler seyahatleri esnasında bütçelerinin yaklaşık \%40 'nı yeme-içme ihtiyaçları için ayırmaktadır (Ab Karim, 2016). Turistlerin temel gereksinimleri olan ulaşım ve konaklamanın yanı sıra yiyecek-içeceklerde bağımsız bir alternatif turizm türü olarak değerlendirilmektedir. Bu noktada gastronomi turizmi farklı turizm türleri ile birlikte kullanılabileceği gibi başlı başına çekicilik unsuru olarak da faaliyet göstermektedir. Gastronomi turizmi her ne kadar yeni bir turizm türü olarak ele alınsa da yabancı ülkeler gastronomiyi tur operatörleri ve seyahat acenteleri aracılığıyla uzun zamandan beri turizm ürünü olarak pazarlamaktadır (Chaney ve Ryan, 2012; Günlü ve Şahin, 2007). Türkiye mevcut gastronomik değerleri ile gastronomi turizmi potansiyeline sahip olsa da henüz etkin bir şekilde kullanılmamaktadır (Şahin ve Ünver, 2015).

Turistlerin farklı bir bölgeye ya da yöreye ait yemekleri deneyimleme amacının yanı sıra üretim süreçlerini görmek için üreticileri, yemek festivallerini ve restoranları ziyaret etmesi (Hall vd., 2003) şeklinde tanımlanan gastronomi turizminin asıl amacı yerel yiyecek ve içecekler ile turistler için motivasyon kaynağı oluşturmasıdır (Birdir ve Akgöl,2015:58). Bu kapsamda Türkiye'nin bölgeler bazında yöresel yemeklerinin tespit edilmesi ve pazarlanması gerekliliği ortaya çıkmaktadır. Konu ile ilgili yazında çeşitli çalışmalar (Hamamcıbaşı, 2006; Okumuş vd., 2007; Dilsiz, 2010; Cömert, 2014; Aksoy ve Sezgi; 2015 Aydoğdu ve Duman; 2017; Başaran, 2017; Özleyen ve Tepeci, 2017; Zengin ve Işkın, 2017; Güzel ve Önçel; 2018, Çelik, 2018; Turan ve Akoğul, 2019; Şeker ve Hastaoğlu, 2020) mevcuttur. Yapılan araştırmalar göz önünde bulundurulduğunda Türkiye'nin farklı bölgelerine yönelik gastronomi turizmi ile ilgili çalışmaların eksikliğinden bahsetmek mümkündür. Bu doğrultuda zengin bir mutfak kültürüne sahip olan Elazığ ilinin yöresel yemeklerinin incelenmesi amaçlanmaktadır. Yapılan literatür taraması sonucunda Elazığ'a yönelik ilgili çalışmaların kısıtlılı̆̆ bu araştırmanın önemini vurgulamaktadir.

\section{KURAMSAL ÇERÇEVE}

Gastronomi kelimesi, Yunanca' da "gaster" (mide) ve "nomas"(yasa) sözcüklerinden türetilmiştir (Çelik, 2018). Kavramsal olarak değerlendirildiğinde farklı yazarlar tarafından çeşitli tanımlamalara rastlamak mümkündür. Kivela ve Crotts (2005) gastronomi kavramını ülkelerin ve aynı coğrafyada yer alan bölgelerin mutfaklarını birbirinden farklılaştıran, bir ulusa veya bölgeye özgü yiyecekleri, beslenme alışkanlıklarını ve gıdaları hazırlama usulleri şeklinde açıklamaktadır. Türk Dil Kurumu Sözlüğünde ise, Gastronomi; "Yemeği iyi yeme merakı, sağglığa uygun, iyi düzenlenmiş, hoş ve lezzetli mutfak, yemek düzeni ve sistemi" olarak tanımlanmaktadır (www.sozluk.gov.tr). Gastronominin yiyecek ve içeceklerden zevk alma ile ilgili olduğu söylenilebilir (Richards, 2002:7). Bu ifade ile gastronominin ana unsurunun insan olduğu görülmektedir. Gastronomik değerler, kültür, toplum, coğrafya, beslenme alışkanlıkları gibi 
birçok unsuru kapsamaktadır (Gillespie ve Cousins, 2001: 2). Bir başka ifadeyle gastronomi, insanların beklentilerini karşılama amacı ile kültürel alışkanlıklar, bilgi, beceri ve emek faktörlerinin bir araya gelmesi olarak tanımlanmaktadır (Hatipoğlu, 2010: 5; Ölmez, 2017: 9).

Genel anlamı ile gastronomi, insanların yaşamsal faaliyetlerini sürdürebilmesi için gerekli olan beslenme unsurları ile ilgili bilgi envanterinin oluşturulması şeklinde tanımlanmaktadır (Cohen ve Avieli, 2004: 733). Bir başka tanıma göre ise gastronomi, hazırlanan özel bir yiyecek ürününü deneyimlemek, yemeklerin hazırlanma şekillerini görmek ve öğrenmek, ünlü şeflerin hazırladıkları yemeklerin tadına bakmak şeklinde ifade edilmektedir (Yüncü, 2010). Gastronomi turizmi ise bu amaç doğrultusunda farklı yiyecek ve içecek ürünlerini deneyimle maksadıyla seyahat motivasyonu oluşturan ve seyahat hareketliğine ön ayak olan bir turizm türüdür (Deveci, Türkmen ve Avcıkurt, 2013: 30). Long (2010) gastronomi turizmini, farklı mutfak kültürüne ait yiyeceklerin üretimini, sunumunu, tüketimini, mutfağını ve yemek yeme biçimlerini görme amacıyla yapılan seyahatler olarak tanımlamaktadır. Gastronomi turizmi, turistlerin seyahatleri esnasında bir yöreye özgü yiyecek ve içecekleri tatma imkânı sunarak başka bir yörede rastlanılması mümkün olmayan gıda ürünlerini deneyimleme fırsatı sunan bir turizm çeşididir (Çatır ve Ay, 2018). Tikkanen (2007) turizm ve gastronomi arasındaki ilişkiyi dört unsur ile açıklamaktadır. Bunlardan ilki gastronomi ve turizm ayrılmaz bir bütündür, ikincisi gastronomi destinasyonun çekicilik unsurudur, üçüncüsü yerel mutfak, yeme içme motivasyonun da kullanılmaktadır ve son olarak gastronomi yerel kültürün bir parçasıdır şeklinde belirtmektedir.

Turizm çeşitlendirmesinde alternatif seçenek olan gastronomi turizmi kapsamında ağırlıklı olarak yerel ürün ve mutfakların ön plana çıkarılması, gastronomi turizmini yerel ve bölgesel ölçekte turizmin gelişimi açısından önemli hale getirmektedir. Bu bağlamda deniz turizmine yönelik hizmet verme imkânı olmayan bölgeler, kültür, tarih, spor, sağlık, gastronomi gibi güçlü yönlerini ortaya koyarak turizmden pay almayı amaçlamaktadır. Bu husus bazı destinasyonlar açısından alternatif turizm çeşitlerinin dikkate alınması gerçeğini vurgulamaktadır (Turan ve Akoğul, 2019). İlgili yazın incelendiğinde destinasyonlar için gastronomi turizmi ve yerel ürünlerin önemini vurgulayan bazı çalışmalar mevcuttur. Aydoğdu, Okay ve Köse (2016), Bozcaada'yı ziyaret eden turistlerin destinasyon seçiminde gastronomi turizminin turizm talebinde rol oynayabileceği ve bir çekim unsuru olarak kullanılabileceği şeklinde değerlendirmiştir. Polat (2020), Kahramanmaraş ilinin yöresel yemek imajının destinasyon tercihine etkisini konu alan çalışmasında, yöresel yemek imajının destinasyon tercihinde pozitif ve anlamlı bir etkisi olduğunu belirlemiştir. Aynı zamanda yöresel yemeklerin gastronomi turizminde önemli bir yeri olduğu anlaşılmıştır. Kivela ve Crotts (2006), gastronominin, turistlerin bir destinasyonu ziyaret etmelerindeki etkisini tespit etmeyi amaçlamışlardır. Araştırma Hong Kong Adası ve Kowloon bölgesinde 1200 kişi ile anket aracıllı̆ı̆yla gerçekleştirilmiştir. Sonuç olarak gastronominin bir bölgeyi ziyaret etme niyetinde etkili olduğuna ulaşılmıştır. Güzel ve Önçel (2018) "Gastronomi Şehri" unvanı alan Hatay ilinde, destinasyonların çekicilik unsuru olmasında gastronomi turizminin rolünü incelemişlerdir. Bu kapsamda Hatay'ı ziyaret eden ve yöresel yemek satışı sunan yiyecek içecek işletmelerini tercih eden 15 turist ile görüşme gerçekleştirilmiştir. Yapılan analizler sonucunda gastronomi turizminin Hatay ili için bir çekicilik unsuru olduğu sonucuna ulaşılmıştır. Aydoğdu ve Duman (2017) Gastronomi Turizminin Kastamonu ili için çekicilik unsuru olarak kullanılabilirliğini tespit etme amacıyla yaptıkları çalışmada Kastamonu yöresel yemeklerinin il için bir çekim gücü oluşturduğu belirtilmektedir. Enright ve Newton (2005) yemeğin önemli bir çekicilik faktörü olduğuna değinmiştir. Çalışma sonucunda yemeğin çekicilik faktörü olarak Hong Kong için ikinci sırada, Bangkok'ta dördüncü Singapur'da beşinci sırada yer aldığı tespit edilmiştir. Hall ve Sharpler (2003), tur organizasyonları çerçevesinde turistik bir bölgeyi ziyaret eden turistler için yiyecek ve içeceklerin önemli bir faktör olduğunu ve bölgeye ait yemekleri tükettiklerini, bu 
ürünleri satın alma niyetinde bulunduklarını ve yerel pazarları ziyaret ettiklerini belirtmiştir. Renko vd., (2010:232), yerel mutfakları bir bölgenin kimliğini oluşturan ve sahiplenme duygusunu ön plana çıkararak turistik deneyimlere değer katan bir unsur olarak açıklamaktadır. Lee ve Arcodia (2011), yemekleri bir destinasyonu diğerlerinden farklılaştırmada kullanılabileceğini ve o bölgenin kültürünü tanıtabileceği konusunda açılamalarda bulunmaktadır. Benzer bir ifadede Plummer vd., (2005) turistlere bir destinasyon kültürünü tanıtmada yiyecek ve içeceklerin önemli olduğuna ve yöresel ürünlerin turizm kapsamında değerlendirilmesi gerektiğine değinmektedir. Gastronomi turizminin genel olarak yerel mutfak kültürü öğelerinin zengin olduğu destinasyonlara çekicilik gücü kazandırdığı ve turistlerin bir destinasyonu tercih etme niyetinde etkili olduğundan bahsedilmektedir (Turan ve Akoğul, 2019:374). Turizm ile yiyecek ve içecek deneyimi birlikte değerlendirildiğinde yöresel mutfak kavramı bu deneyimin önemli bir parçasıdır (Şengül ve Türkay,2016). Yöresel mutfaklar geçmişten günümüze değişime uğrayarak gelmiş olmasıyla birlikte yöre halkının farklı tarifleriyle de ortaya çıkmış olabilirler. Yörenin sahip olduğu iklim özellikleri, coğrafi şekiller ve bölgeye has özelliklerinin harmanlanmasıyla yöreye has yemekler oluşmuştur. Yöresel yemekler bölgeyi ziyaret için gelen turistler açısından oldukça önemlidir (Şengül ve Türkay, 2016). Yöresel mutfak ve gastronomi turizmi ilişkisi ile ilgili Everett ve Aitchison (2008)'nun İngiltere, Cornwall'da yaptıkları çalışmada, katılımcıların yöresel mutfak ürünlerine diğer yiyecek ürünlerine oranla daha fazla ödeme yapabilecekleri sonucu ortaya çıkmıştır. Şengül ve Genç (2016) festival turizmi kapsamında yöresel mutfak kültürünün destekleyici ürün olarak kullanılması ile ilgili yaptıkları araştırmada yöresel yiyecek ve içeceklere olan talebin birçok turistik ürün pazarlamasında destekleyici rol üstlenebileceğini belirtmektedir.

Dünyanın en zengin mutfakları arasında yer alan Türk mutfağının doğru bir konumlandırma yapılarak ve imajının oluşturulmasıyla destinasyon markalaşmasına önemli katkılar sağlayacaktır (Cömert,2014:65). Türkiye'nin sahip olduğu mutfak kültürünün bölgesel olarak farklılaştığ 1 ve bölgelerin kendilerine has özellikleri göz önünde bulundurulduğunda gastronomi turizminin farklı turizm türleri ile birlikte kullanılması adına büyük avantajlar sağlamaktadır. Turist beklentilerinin her geçen gün değiştiği gözetildiğinde bölgesel mutfak kültürünün tanıtımı turistik ürün çeşitlendirmesi ve sürekliliğinin sağlanması açısından oldukça önem arz etmektedir (Hu ve Ritchie,1993 akt., Şengül ve Türkay, 2016; Gross, Brien ve Brown, 2008). Gastronomi turizminin farklı turizm türleri ile ilişkilendirilerek kullanılabileceği hususu göz önünde bulundurulduğunda Elazığ ili sahip olduğu doğal, tarihi arkeolojik ve kültürel değerleri ve yöresel mutfak unsurları ile zengin bir turizm potansiyeline sahiptir. Elazığ mutfak kültürüne yönelik yapılan çalışmalar oldukça kısıtlıdır (Güleç, 2020; Şimşek ve Güleç, 2020). Yapılan çalışmalar incelendiğinde çoğunlukla şehrin turizm potansiyeli genel olarak ele alınmıştır (Kabasakal, 1993; Torun, 2015). Yapılan açıklamalar doğrultusunda bu çalışmada Elazı̆̆'ın yöresel mutfak kültürünün önemli bir parçası olan yöresel yemekleri gastronomi turizmi çerçevesinde incelenmiştir.

\section{Elazı̆̆ İli Hakkında Genel Bilgiler}

Elazığ ili Doğu Anadolu Bölgesi'nin güneybatısında, Yukarı Fırat Bölümü'nde yer almaktadır. 1067 metre rakıma sahip Elazığ, yeryüzü şekilleri bakımından platolar, dağlık alanlar ve ovalardan oluşmaktadır. Elazığ ilinin Türkiye haritasındaki yeri Şekil 1'de verilmiştir.

Coğrafi konumu nedeniyle Elazığ doğuyu batıya birleştiren yolların kavşağı konumundadır. Doğudan Bingöl, kuzeyden Keban Baraj Gölü vasıtasıyla Tunceli, batı ve güneybatıdan Karakaya Baraj Gölü aracılığıyla Malatya, güneyden ise Diyarbakır ilinin arazilerini çevrelemektedir. Elazığ' da karasal iklimin etkileri görülmektedir. Keban barajı kurulduktan sonra zaman zaman 
Akdeniz iklimi ile karasal iklim arasında geçişler söz konusu olmaktadır. Şehrin genel olarak ekonomik yapısı tarım, hayvancılık, madencilik, sanayi ve hizmet sektörüne dayanmaktadır (Torun, 2015:36). Türkiye İstatistik Kurumu 2019 verilerine göre ilin nüfusu 591.098'dir (data.tuik.gov.tr).

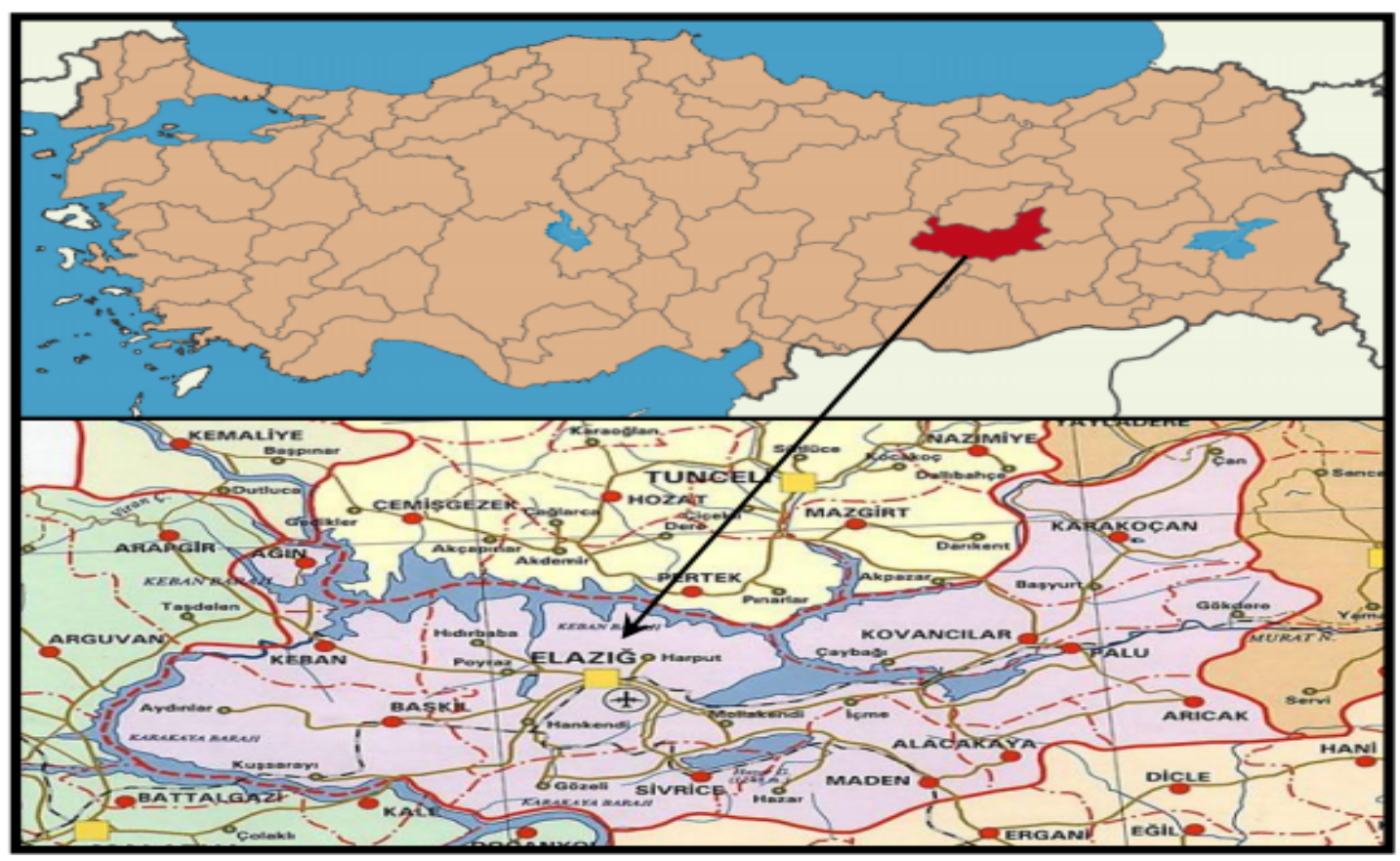

Şekil 1. Elazı̆̆’’n Türkiye Haritasındaki Yeri

Kaynak: https://www.turkiye-rehberi.net/ ve https://commons.wikimedia.org/wiki/Main_Page

\section{Elazı̆̆ Mutfağı ve Yöresel Yemekleri}

Elazığ mutfak kültürü Türk mutfağının izlerini taşımaktadır. İklim, coğrafi özellikler ve bölgede yetişen ürün çeşitliliğinin etkisiyle yemeklerin büyük bir kısmı sadece Elazığ iline özgüdür (www.elazig.gov.tr). Ankara Ticaret Odası ve Ankara Patent Bürosu'nun düzenlemiş olduğu Türkiye lezzet haritasında Gaziantep ilinden sonra 154 çeşit yiyecek-içecek ürünü ile en zengin il olarak belirlenmiştir (Durlu-Özkaya ve Can, 2012; akt. Tuna ve Özyurt, 2018)

Zengin bir içeriğe sahip Elazığ mutfağında Harput yöresi dâhil olmak üzere bazı yerlerde yalnızca iki öğün yemek tüketimi gerçekleşmektedir. Bunlardan biri kuşluk (sabah ile ikindi arası) diğeri ise ikindi ve akşam vakitleri arası tüketilen yemeklerdir. Bu iki öğüne ek olarak gece vakitlerinde taze meyve ya da kuruyemişlerin tüketildiği yatsılık zamanları vardır. Yerel halk tarafından genel olarak sabah, öğlen akşam olmak üzere 3 öğün yemek tüketilmektedir (www.kulturportali.gov.tr).

Tüketimi gerçekleştirilen yemeklerin mevsimsel olarak yaz ve kışş şeklinde sınıflandırılmasından söz edilebilmesi mümkündür. Yaz aylarında özellikle sabah kahvaltılarında; "Çökelek, tereyağı, zeytin, süt kaymağı, bal, Yağlı ekmek, Yağlanmış petil (yufka ekmeği), Kavut (yağda kavrulmuş un), Tel kebabı (biber kebabı)"vb. içecek olarak da genel olarak da çay bulunmaktadır. Öğle yemekleri genel olarak öğle namazından sonra yenilmektedir. "Etli veya zeytinyağlı fasulye, Pirpirim (semizotu) yemeği, Söğürtme, Güveç" vb. yiyecekler tüketilmektedir. Yemeklerin yanında özeme ve yayık ayranı servis edilmektedir. Yaz aylarının en önemli yemeği ise "Yarpuzlu ayranlı çorba" başta olmak üzere Yayla çorbası, Yoğurtlu bulgur ve Gıldırikli köfte" yemekleridir. Akşam yemekleri 
"Sarma, Dilim dolma, Harput köftesi, Karnıyarık, Bulgur pilavı, Melemen" vb. yemeklerdir (www.elazig.ktb.gov.tr).

Kış aylarında sabah kahvaltılarında mutlaka pekmez, tahin, küncü ezmesi veya bal, tereyağ bulundurulmaktadır. "Gaygana, Kavurmalı yumurta, Peynirli patila, Kuru biber ve kuru domates kavurması" da tüketilen gıda ürünleri arasındadır. Öğle yemeklerinde genellikle kış ayında tüketilen çorbalar önemli bir yer tutmaktadır. Bu çorbalara "Tarhana", Erişte, "Lobik" mercimek" örnek olarak verilebilir. Ana yemek olarak Kuru fasulye, Bulgur pilavı, (mevsime göre patlıcan veya patates tercih edilir)" vb. yemekler tüketilir. Akşam yemeklerinde ise öğle vakti tüketilen yemekler geçerlidir. Bu duruma ek olarak İçli köfte, Gömme, Kaburga dolması, Ufalama, Kofik dolması, Keşkek, Bumbar" vb. yemekler örnek olarak verilebilir (www.elazig.ktb.gov.tr).

Elazığ mutfak kültüründe bulunan diğer yiyecek- içecek ürünleri gerçekleştirilen görüşmeler ve ikincil kaynaklardan elde edilen veriler gruplandırılarak ilgili tablolarda yer verilmiştir. Örnekleri verilen yemek tarifleri yapılış şekilleri bakımından farklılık gösterdiği için ürünlerin miktarları belirtilmemiştir ve genel olarak ham malzeme listelerine yer verilmiştir. Tarif örnekleri katılımcların Elazı̆̆ mutfağı içerisinde önemli bir yere sahip olduğu düşünülen yiyecek ürünlerinden oluşmaktadır. Yemek isimleri ve tarifler ile ilgili görüşme esnasında farklı sonuçlara ulaşıldığından daha güvenilir bilgiler vermek amacıyla Elazığ Valiliğgi (2020), Elazığ İl Kültür ve Turizm Bakanlığı (2020) internet siteleri ve Güleç (2020) 'in "Elazığ Gastronomik Kimliğinin Destinasyon İmajı Açısından Değerlendirilmesi" isimli yüksek lisans tezinden yararlanılmıştır.

\section{ARAŞTIRMANIN AMACI ve YÖNTEM}

$\mathrm{Bu}$ araştırmanın amacı Elazı̆̆ mutfak kültürüne ait yöresel yemeklerinin incelenmesidir. Bu kapsamda öncelikle yöreye ait yemeklerin tespit edilmesi amacıyla, nitel araştırma yöntemlerinden görüşme tekniği tercih edilmiştir. Araştırma evrenini Elazı̆̆ Merkez ilçesinde yaşayan ev hanımları oluşturmaktadır. Araştırmada ölçüt örnekleme metodu kullanılmıştır. Ölçüt örnekleme, önceden belirlenen bir dizi kriteri karşılayan durumların incelenmesidir. Bu kriterler araştırmacılar tarafından oluşturulur veya daha önceden tespit edilmiş kriterler kullanılmaktadır (Marshall ve Rossman, 2014; akt. Baltacı, 2018: 254). Araştırma örneklemini Elazığ/Merkez ve farklı ilçelerinde doğmuş, halen burada ikamet eden, belirli bir kültürel birikime sahip olduğu düşünülen 40 yaş ve üzeri 13 ev hanımı oluşturmaktadır. Araştırmacının, bu bölgede uzun süre yaşamış olması araştırma için doğru kişilerin tespit edilmesine imkân tanımaktadır. Buna ek olarak, ikincil veri kaynaklarından yararlanılmıştır. Katılımcılardan elde edilen veriler 15.12.2020-02.01.2021 tarihleri arasında pandemi süreci ve maddi kisitlllıklardan dolayı telefon ile görüşmeler sağlanarak elde edilmiştir. Araştırmaya kaynak olabileceği düşünülen kişilere (Başaran, 2017)'nin "Gastronomi Turizmi Kapsamında Rize Yöresel Yöresel Lezzetlerinin Değerlendirilmesi" isimli çalışmasından yararlanılarak yemeklerin isimleri, içerikleri ve tüketim şekillerine ilişkin sorular sorulmuş ve yanitlar görüşme formuna kaydedilmiştir. Görüşmeler yaklaşık olarak 20-25 dakika sürmüştür ve görüşme gerçekleştirilen her bir katılımcı "Katılımcı 1" şeklinde kodlanmıştır. Elde edilen verilerin analizinde betimsel analiz tercih edilmiştir.

\section{BULGULAR}

Çalışma kapsamında görüşme gerçekleştirilen bireylere ilişkin demografik bilgiler Tablo 1'de verilmiştir. 
Tablo 1. Katılımcılara Ait Demografik Bilgiler

\begin{tabular}{|c|c|c|c|c|}
\hline Katılımcılar & Cinsiyet & Yaş & Mesleği & Doğum Yeri \\
\hline Katılımcı 1 & Kadın & 60 & Ev Hanımı & 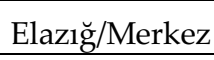 \\
\hline Katılımcı 2 & Kadın & 48 & Ev Hanımı & 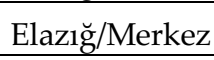 \\
\hline Katılımc1 3 & Kadın & 40 & Ev Hanımı & Elazı $\breve{g} /$ Maden \\
\hline Katılımci 4 & Kadın & 47 & Ev Hanımı & Elazı $\breve{g} / M e r k e z$ \\
\hline Katılımc1 5 & Kadın & 52 & Ev Hanımı & Elazı $\breve{g} /$ Merkez \\
\hline Katılımci 6 & Kadın & 50 & Ev Hanımı & 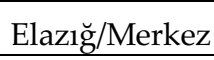 \\
\hline Katılımcı 7 & Kadın & 42 & Ev Hanımı & Elazı ̌̆/Merkez \\
\hline Katılımc1 8 & Kadın & 43 & Ev Hanımı & Elazığ/Sivrice \\
\hline Katılımc1 9 & Kadın & 55 & Ev Hanımı & 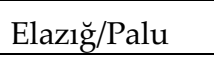 \\
\hline Katılımc1 10 & Kadın & 60 & Ev Hanımı & 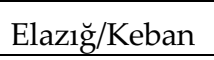 \\
\hline Katılımcı 11 & Kadın & 68 & Ev Hanımı & Elazı̆̆/Merkez \\
\hline Katılımc1 12 & Kadın & 75 & Ev Hanımı & 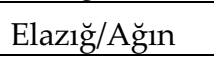 \\
\hline Katılımcı 13 & Kadın & 72 & Ev Hanımı & Elazı $\breve{g} / M e r k e z$ \\
\hline
\end{tabular}

Tablo 1'de katılımcıların araştırmanın amacına uygun olarak tamamının ev hanımlarından oluştuğu ve Elazığ/Merkez ve farklı ilçelerinde doğup büyüyen kişiler olduğuna dikkat çekilmektedir. Veri toplama amacına yönelik 40 ve üzeri yaş ölçütü dikkate alındığında çeşitli yaş grubundaki kadınlarla görüşmeler gerçekleştirilmiştir.

Elazı ̆ ili, bulunduğu konum itibariyle malzeme çeşitliliği açısından zengin bir mutfak yapısına sahiptir. Elazığ mutfağında bulunan yemek türleri gruplandırıldığında çorbalar farklı bir kategori içerisinde ele alınmıştır. Katılımcılara Elazığ mutfak kültüründe yer alan çorbaların isimleri hakkında bilgi verir misiniz? sorusu yöneltilmiş alınan cevaplar Tablo 2.'de belirtilmiştir.

Tablo 2. Elazığ Mutfak Kültüründe Yer Alan Çorbaların İsimlerine İlişkin Bulgular

\begin{tabular}{|l|l|}
\hline Ayranlı Köfte Çorbası & (Katılımc1 1,4,5,7,8,13) \\
\hline Borani & (Katılımc1 1, 4, 5, 9, 10, 11, 12) \\
\hline Kelle Paça Çorbası & (Katılımc1 2, 6, 8,11,12) \\
\hline Kurutlu Çorba & (Katılımc1 1,7,10,12, 13) \\
\hline Lobik Çorbası & (Katılımc1 1,2,3,4,5,6,8,10,13) \\
\hline Mukaşerli Erişte Çorbası & (Katılımc1 1,4,7,11,12,13 \\
\hline Püşürük Çorbası & (Katılımc1 3,5,8,10,11) \\
\hline Sebzeli Bulgur Çorbası & (Katılımc1 1,3,8,9,12,13) \\
\hline Taze Fasulye Çorbası & (Katılımc1 2,6,7,8,10) \\
\hline Yarpuzlu (Naneli) Ayran Çorbası & (Katılımc1 4,5,6,11,13) \\
\hline Tarhana Çorbası & (Katılımc1 1,2,3,4,5,6,7,8,9,10,11,12,13) \\
\hline Tutmaç Çorbası & (Katılımc1 2,4,7,12,13) \\
\hline
\end{tabular}

Tablo 2"de Elazığ mutfağında yer alan 12 adet çorba türünden bahsetmek mümkündür. İlgili tabloda yer verilen çorba türlerine ek olarak katılımcılardan $(1,3,10,11,12,13)$ elde edilen bilgiler çerçevesinde "Mercimek çorbası, Yoğurtlu erişte çorbası, Ezogelin çorba, Un çorbası, Domates çorbası, Tavuk çorbası" gibi farklı bölgelerde sıklıkla tüketilen çorbalara da yemelerde yer verildiği sonucuna ulaşılmıştır.

Elazığ mutfağına ait çorbaların genel içerikleri ile ilgili katılımcıların verdiği ortak yanıtlar şu şekildedir: 
"Kış aylarında sıklıkla tükettiğimiz çorbalar için yaz ayından erişte, kurut, tarhana ve taze domateslerimizi konserve haline getirip hazırlıklarımızı yapıyoruz" (Katılımc1 1,4,8).

"Çorbalarımız da genellikle nohut, mercimek, bulgur, lobik (kuru börülce) ve erişteyi genç yaşlarda yemek yapmaya başladığımızdan itibaren kullanıyoruz" (Katılımc1 9).

"Mevsimlere göre evde yaptığımız çorbalar değiş̧iklik gösterebiliyor. Yaz aylarında köylerimize gittiğimiz zaman tarladan topladığımız pirpirim(semizotu) ile yoğurdu belirli bir miktar sulandırdıktan sonra karıştırıp hızlı bir şekilde çorba yapmayı tercih ediyoruz. Bazı zamanlar tok tutması için bir gece öncesinden bulgurdan köfte yapıp ertesi gün aynı şekilde yoğurt ile karıştırı tükettiğimiz zamanlar oluyor. Yaptığımız yapuzlu(nane) ayran çorbasını da yarpuzlarımızı bahçelerimizden toplayıp veya şehirde olduğumuz zaman dışarıdan alıp yoğurdu sulandırıp çorba yapıyoruz" (Katılımcı,10,11).

"Eskiden kelle paça çorbası gibi sakatat çorbaların büyüklerimizle köylerde özellikle kurban kestikleri zaman hemen peşinden odun ocakları kurup çorba yapardık. Ancak biz çocuklarımızın kokudan rahatsız olmaması için eskisi kadar evlerimizde hazırlamıyoruz. Zaten eskisi kadar özellikle genç hanımlar, böyle bir alışkanlıkları olmadığı için bu çorbaları kendileri de evlerinde yapmıyorlar" (Katılımcı 12).

"Et, tereyağı, hatta etlerin kemiklerini kaynatıp çorbalarımızda kullanmayı tercih ediyoruz. Özellikle kış aylarında dinç tuttuğunu düşünüyoruz. Kış aylarında bunun dışında săğlklı olacağı düşüncesiyle sürekli olarak sebzeli bulgur çorbası, kurutlu çorba, yazın dolapta dondurduğumuz fasulye ile yaptığımız taze, fasulye çorbasını da sıklıkla tüketiyoruz (Katılımcı, 2, 12).

Tereyağı, pul biber, kuru nane, sarımsak, domates salçasımı kavurup çorbaların üzerine hem iştah arttırsın diye hem de lezzetini arttırması için kullanıyoruz. Çünkü çorbalar bizim için her öğünde yediğimiz yemekler biz bunu zamanla nasıl güzel bir şekilde ikram edebiliriz düşüncesiyle bu yolu kullanarak kendimize alışkanlık haline getirdik (Katılımcı 13).

Katılımcılardan elde edilen bilgiler ışığında Elazığ mutfak kültüründe yer alan çorbaların genellikle kuru baklagillerden oluştuğu yorumunun getirilmesi yerinde olacaktır. Tereyağı ve et gibi hayvansal ürünlerin çorbalarda özellikle sağlık amaçlı kullanıldığı sonucuna ulaşılmıştır. Bunun haricinde yoğurdun hem yeşilliklerle hem de tahıl ürünleri ile karıştırılıp çorba olarak tüketildiğinden bahsedilmektedir. Elazığ mutfağında yer alan çorbaların soğuk ve sıcak olarak farklılaştığından bahsedilmesi mümkündür. Aşağıda bazı çorba çeşitlerine örnek verilmiştir.

\section{Lobik Çorbası}

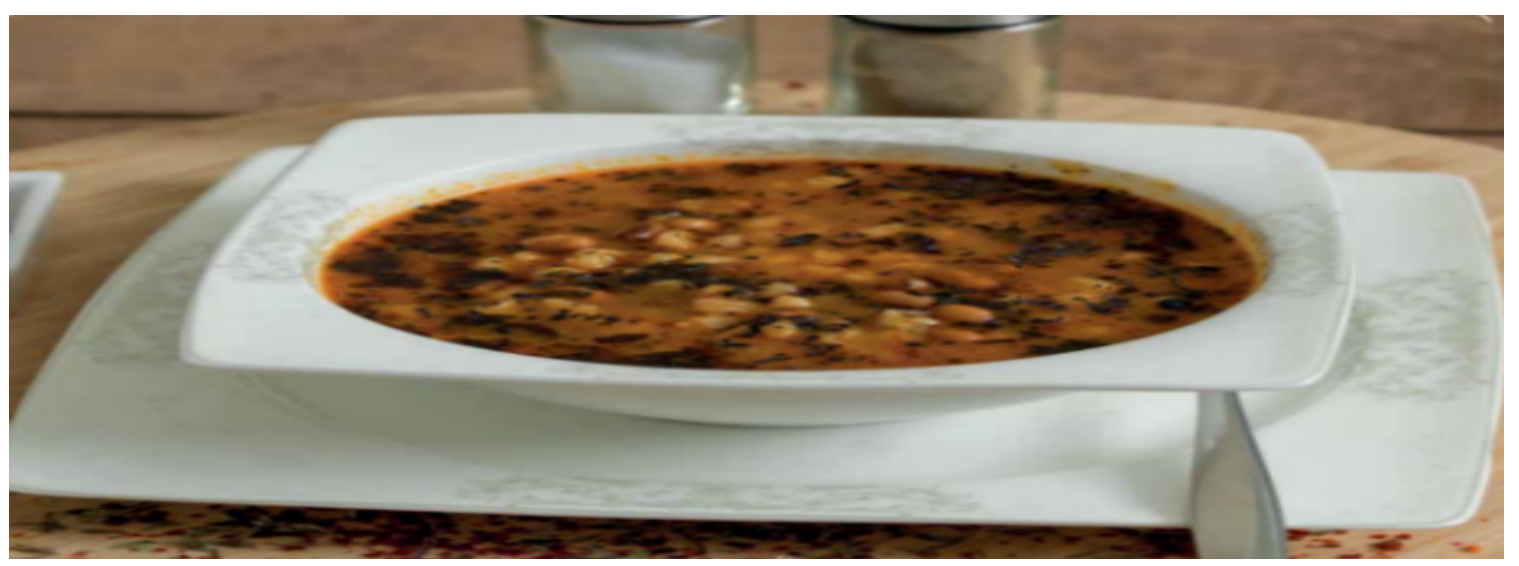

Resim 1. Lobik Çorbası

Kaynak: (www.elazig.ktb.gov.tr). 
Malzemeler: Lobik (Börülce), döğme (aşurelik buğday), tereyağı, kuru soğan, domates salçası, biber salçası, su (veya et suyu), kuru nane, tuz.

Yapılışı: Lobikler bir gece önce suda bekletilir. Bir sonraki gün suda yaklaşık 20 dakika haşlanır. Ayrı bir tencerede, yemeklik doğranmış soğan tereyağı ile kavrulur. Salçalar eklenerek 2 dakika daha kavrulur. 2 bardak su (veya Et suyu) ilave edilir ve kaynamaya birakılır. Döğmeler kaynayan suyun içerisine eklenir ve pişirilir. Üzerine tuz ve lobikler eklenerek 15-20 dakika daha pişirilir. İsteğe bağlı olarak pişmeye yakın içerisine kuru nane ilave edilebilir. Sıcak olarak servis edilir (elazig.ktb.gov.tr).

\section{Ayranlı Köfte Çorbası}

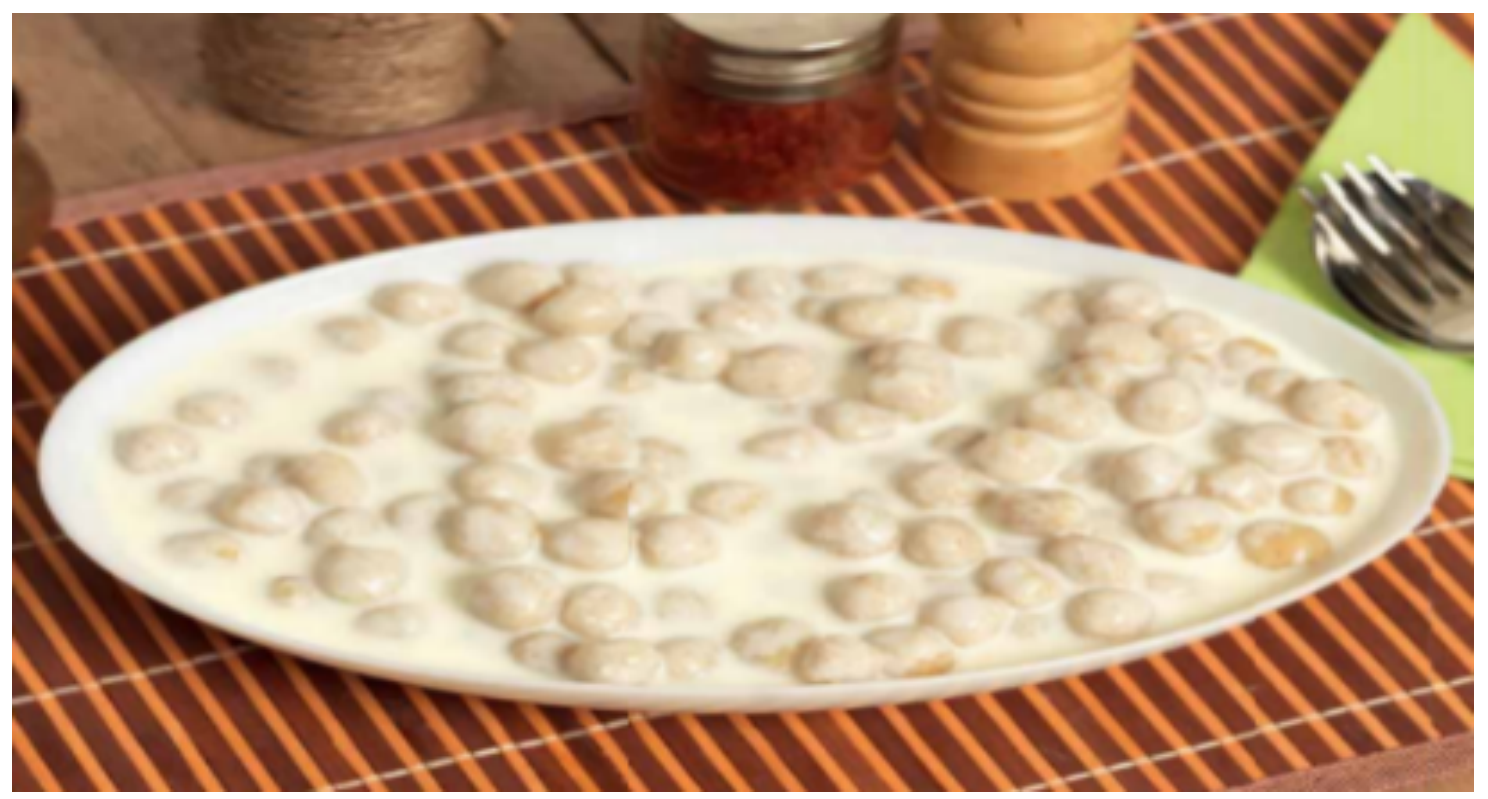

Resim.2 Ayranlı Köfte Çorbası

Kaynak: (www.elazig.ktb.gov.tr).

Malzemeler: Yoğurt, Köftelik İnce Bulgur, Un, Yumurta, Su, Sarımsak, Pul Biber, Tereyağı, Nane, Tuz.

Yapılışı: Bulgur geniş bir tepsinin içerine alınarak sıcak su ilave edilir. Tepsinin üzeri sarılarak 30 dakika bekletilir. Bulgur yumuşadıktan sonra üzerine un ve yumurta ilave edilerek karıştırılır. Karışım köfte kıvamına geldikten sonra elde fındık büyüklügünde yuvarlanır. Bir tencerede su kaynatılır ve yaklaşık 5 dakika pişirilir. Pişirilen köfteler süzgece alınarak sularından arındırılır ve yaklaşık 25 dakika dinlendirilir. Yoğurt ayrı bir kapta çırpılır, su, tuz ve sarımsak ilave edilir. Yoğurt karışımının koyu bir kıvamda olması beklenir. Bahsedilen karışım köftelerin üzerine ilave edilir. Son olarak ocakta tereyağı eritilerek pul biber ile servis edilir (www.elazig.ktb.gov.tr).

Elazı ̆̆ mutfağında bulunan yemek türleri gruplandırıldığında içerisine pilav ve sebze yemeklerinin de dâhil edildiği yemekler ana yemek olarak kategorize edilmiştir. Katılımcılara Elazığ mutfak kültüründe yer alan yemeklerin isimleri hakkında bilgi verir misiniz? sorusu yöneltilmiş alınan cevaplar Tablo 3'de belirtilmiştir. "Süslü fidoş ve Taraklık" yemeği ile ilgili bilgiler "(www.elazig.ktb.gov.tr)" internet sitesinden yararlanılarak tabloya eklenmiştir. 
Tablo 3. Elazığ Mutfağında Yer Alan Yemeklerin İsimlerine İlişkin Bulgular

\begin{tabular}{|c|c|}
\hline Aluçalı İşgene & (Katılımcı 1,2,4,7,8,9,10,11,12,13) \\
\hline Ayar Köfte & (Katılımcı 1,2,5,9,13) \\
\hline Ayranlı Keşkek & (Katılımcı 2,5,8,9,10,11,12,13) \\
\hline Bastuğ Kavurması & (Katılımcı 1,2,11,12,13) \\
\hline Batırma & (Katılımcı 1,2,3,4,5,6,7,8,10,12,13) \\
\hline Bumbar Dolması & (Katılımcı 1,7,8,11,12,13) \\
\hline Cavzer & (Katılımcı 5,9,12,13) \\
\hline Erişte Pilavı & (Katılımc1 1,2,3,4,5,6,7,8,9,10,11,12,13) \\
\hline Etli Yaprak Sarması & (Katılımc1 1,2,3,4,5,6,7,8,9,10,11,12,13) \\
\hline Fasulye Kavurması & (Katılımc1 3,7,8,12) \\
\hline Soğan Dolması & (Katılımcı 1,2, 10,11,12,13) \\
\hline Güveç & (Kat1lımc1 1,2,3,4,5,6,7,8,9,10,11,12,13) \\
\hline Hamur Sarma & (Katılımc1, 1,12,13) \\
\hline Harput Köfte & (Kat1lımc1 1,2,3,4,5,6,7,8,9,10,11,12,13) \\
\hline Hedik & (Kat1lımc1 1,2,3,4,5,6,7,8,9,10,11,12,13) \\
\hline Işkın Mıhlaması & (Katılımcı 1,3,5,6,10,11,12,13) \\
\hline İçli Köfte & (Katılımcı 1,2,3,4,5,6,7,8,9,10,11,12,13) \\
\hline Kaburga Dolması & (Katılımcı 12,13) \\
\hline Kâğğt Kebabi & (Katılımcı 1,10,11) \\
\hline Kara Kavurma & (Katılımc1 1,2,3,4,5,6,7,8,9,10,11,12,13) \\
\hline Kelecoş & (Katılımc1 1,2,4,5,6,7,9,10,12,13) \\
\hline Kuru Kebap & (Katılımc1 1,2,3,4,5,7,8,9,10) \\
\hline Kurutlu Gömme (Zarafat) & (Katılımc1 1,10,11,12,13) \\
\hline Mercimek Köftesi & (Katılımc1 1,2,3,4,5,6,7,8,9,10,11,12,13) \\
\hline Mukaşerli Bulgur Pilavı & (Katılımc1 1,2,3,4,5,6,7,8,9,10,11,12,13) \\
\hline Palu Ekşili Köfte & (Katılımcı 2,4,9) \\
\hline Palu Tava & $($ Katılımcı 2,4,9) \\
\hline Patates Kavurması & (Katılımcı 1,2,3,4,5,6,7,8,9,10,11,12,13) \\
\hline Patlıcanlı Ekşili Köfte (Dilim Dolma) & (Kat1lımc1 1,2,3,4,5,6,7,8,10,11,12,13) \\
\hline Pirpirim (Semizotu)Yemeği & (Katılımc1 1,2,3,4,5,6,7,8,9,10,11,12,13) \\
\hline Reyhanlı Kavurmalı Pilav & (Katılımc1 2,5,6,7,8,10) \\
\hline Sirin & (Katılımc1 1,2,3,4,5,6,7,8,9,10,11,12,13) \\
\hline Soğanlı Kurut Köfte & (Katılımc1 9,12,13) \\
\hline Söğürtme & (Katılımc1 1,2,3,4,5,6,7,8,9,10,11,12,13) \\
\hline Süslü Fidoş & (www.elazig.ktb.gov.tr) \\
\hline Tarakl1k & (www.elazig.ktb.gov.tr) \\
\hline Tavşan Ufalama & (Kat1lımc1 1,2,4,5,6,9,10,11,12,13) \\
\hline Tepsi Tava & (Kat1lımc1 1,2,3,4,5,6,7,8,9,10,11,12,13) \\
\hline Tevekli Pilav & (Katılımcı 1,10,11,12,13) \\
\hline Üsküre Kebabı & (Katılımcı 1,3,4,5,6,7,8,11,12) \\
\hline Yoğurtlu Ispanak Kavurması & (Kat1lımc1 1,2,3,4,5,6,7,8,9,10,11,12,13) \\
\hline Zeytinyağlı/ Etli Nahna (Lahana) Sarması & (Kat1lımc1 1,2,3,4,5,6,7,8,9,10,11,12,13) \\
\hline Zeytinyağl1/Etli Kofik Dolma & (Katılımci 1,2,3,4,5,6,7,8,9,10,11,12,13) \\
\hline
\end{tabular}


Katılıcımlar ile gerçekleştirilen görüşmeler doğrultusunda tespit edilen 43 adet ana yemek çeşidi Tablo 3'de belirtilmiştir. "Aluçalı işgene, Etli yaprak sarması, Güveç, Harput köfte, İçli köfte, Kara kavurma, Mercimek köftesi, Mukaşerli bulgur pilavı, Patates kavurması, Pirpirim (Semizotu) yemeği, Sırın, Söğürtme, Tepsi tava, Yoğurtlu ispanak kavurması, Zeytinyağlı/ Etli nahna (lahana) sarması, Zeytinyağll/Etli kofik dolma" yemeklerine katılımcıların tamamının yanıt verdiği belirlenmiştir. Hamur sarma, Kaburga dolması, Kâğıt kebabı, Palu ekşili köfte, Palu tava, Soğanlı kurut köfte" yemeklerinin ise az sayıda kişi tarafından bilindiği sonucuna varılmıştır. Bu durumun temel nedeninin katılımcılar arasındaki yaş farkı ve Elazığ'ın farklı ilçelerine mensup olmalarından kaynaklandığı düşünülmektedir.

Elazığ mutfağında yer alan yemeklerin genel içerikleri ile ilgili katılımcıların verdiği ortak yanıtlar şu şekildedir:

"Yemeklerde genel olarak krmizı et (kuzu eti, dana eti) kullanmayı tercih ediyoruz"(Katllıma 1, 2, 3, 4, 5, 6, 7, 8).

" Hamur ile et ürünlerini aynı yemek içerisinde kullandığımız çok çeşit var. Zarafat, Tavşan Ufalaması, Cavzer, Gömme, Kelecoş, Hamur Sarma gibi yemeklerde çoğunlukla hamur ve etin beraber yenildiği yemeklerimizdendir" (Katılımc1 10,12,13).

"Biz genel olarak sebze yemeklerinin içerisine et ilavesi yaparak tüketiriz. Fasulye kavurması olsun pirpirim yemeği olsun bunlara çok az kemikli et ilave ederek hazırlarız" (Katılımcı,9). Ancak bazı yemeklerimiz merkezden ve buraya bağh köylerde yapılan yemeklere göre farklı yapılır. Mesela biz içli köftenin dış harcını sadece bulgur hamurundan yaparız. Fakat merkez ve merkeze bağhl köylerde bu yemek dışı sinirsiz kıymadan yapılır. Tabi ki uzun zamandan beri merkezde yaşadığımız için bizde bu yöntemle bu yemeği yapıyoruz. Bununla ilgili aluçalı(erikli) işgene gibi yemekler bizim doğduğumuz ilçede genellikle erik kavrularak içerisine yumurta ilave edilerek hazırlanır. Fakat merkezde genellik et yemeklerinin içerisine ekşilik verme amacıyla bu tür erik, dağ sumağı gibi meyve ve baharatların kullanıldığını söyleyebiliriz" (Katılımc1 3,9,10).

"Yemeklerde genellikle bulgur, nohut, döğme ve pirinci çok sık kullanırı. Özellikle üsküre kebabı, kaburga dolması, pirpirim yemeği, ayranlı keşkek, soğanlı kurut köfte gibi yemeklerde sık kullandığımız malzemelerdir" (Katılımcilar 11,12).

"Pilavları zaman zaman et yemeklerinin yanına hazırladı̆̆ımız da oluyor. Fakat bazı zamanlar sofrada bir salatayla beraberde yalnızca pilavın içerisine et ilave ederek de tüketebiliyoruz. Mesela reyhanlı kavurmalı pilavımız var. Yaz aylarında bağlarımızdan topladı̆̆ımız tevekleri (üzüm yapră̆ı) pilavın içine ekleyerek hazırlayabiliyoruz. Bu genellikle tevekli pilav olarak biliniyor" (Katılımcı 13).

"Sebzelere nohut, fasulye, bulgur ilave ettiğimiz sebze yemeklerimiz olabiliyor. Işgını (yabani ot türü) özellikle bahar aylarında pazarlardan veya seyyar satıcilardan satın alı sıklikla yumurta ile beraber hazırlayıp yiyebiliyoruz" (Katılımc1 12,13).

"Yaz aylarında üzümlerin suyunu çıkarıp kaynattıktan sonra hazırladığımız bastŭ̆ (pestil) var. Bu yiyecek şu an tatl niyetine atıştırmalık olarak tüketiliyor. Ama biz eskiden bunu yağda kavurarak yumurta ekleyip pişirdikten sonra tüketiyorduk. Şu an bu yemeği hazırlayan çok az sayıda ev hanımı var" (Katılımc1 11).

Bahsedilen yemeklerin çoğunluğunun et ürünlerinden oluştuğunu söylemek mümkündür. Görüşme gerçekleştirilen kişiler içeriğinde et olmayan (mercimek köftesi, pirpirim (semizotu) yemeği, fasulye kavurması) sebze yemeklerinin içerisine dahi bazı kesimlerde belirli bir miktar et ilave edildiğinden bahsetmektedir. Katılımcılar aynı zamanda içli köfte, aluçalı (erikli) işgene yemeğinin de Elâzı ̆̆’ın belirli bölgelerinde farklı yöntemler ile yapıldığını belirtmektedir. 
İçli köftenin genel olarak şehrin merkezinde dış harcının yağsız et ilavesi ile yapıldığını belirtirken şehrin doğu kesimlerinde ise yalnızca bulgur hamurundan yapıldığını belirtmektedir. Aynı şekilde aluçalı (erikli) işgenin de il merkezinde kavurma eti ilave edildiği doğu kesiminde kalan köylerinde ise yumurta ilavesi ile yapıldığı belirtilmektedir.

Katılımcılardan elde edilen bilgiler ışığında yemeklerde tahıl ürünlerinin çoğunlukla kullanıldığını söylemek mümkündür. Buna ek olarak eskiden bazı yemeklerin içerisinde ekşi ve tatlı meyvelerden elde edilen ürünlerle hazırlandığı çıkarımında bulunulabilir. Aşağıda Elazı̆̆ mutfak kültürüne has bazı yemek reçetelerine yer verilmiştir.

\section{Harput Köfte}

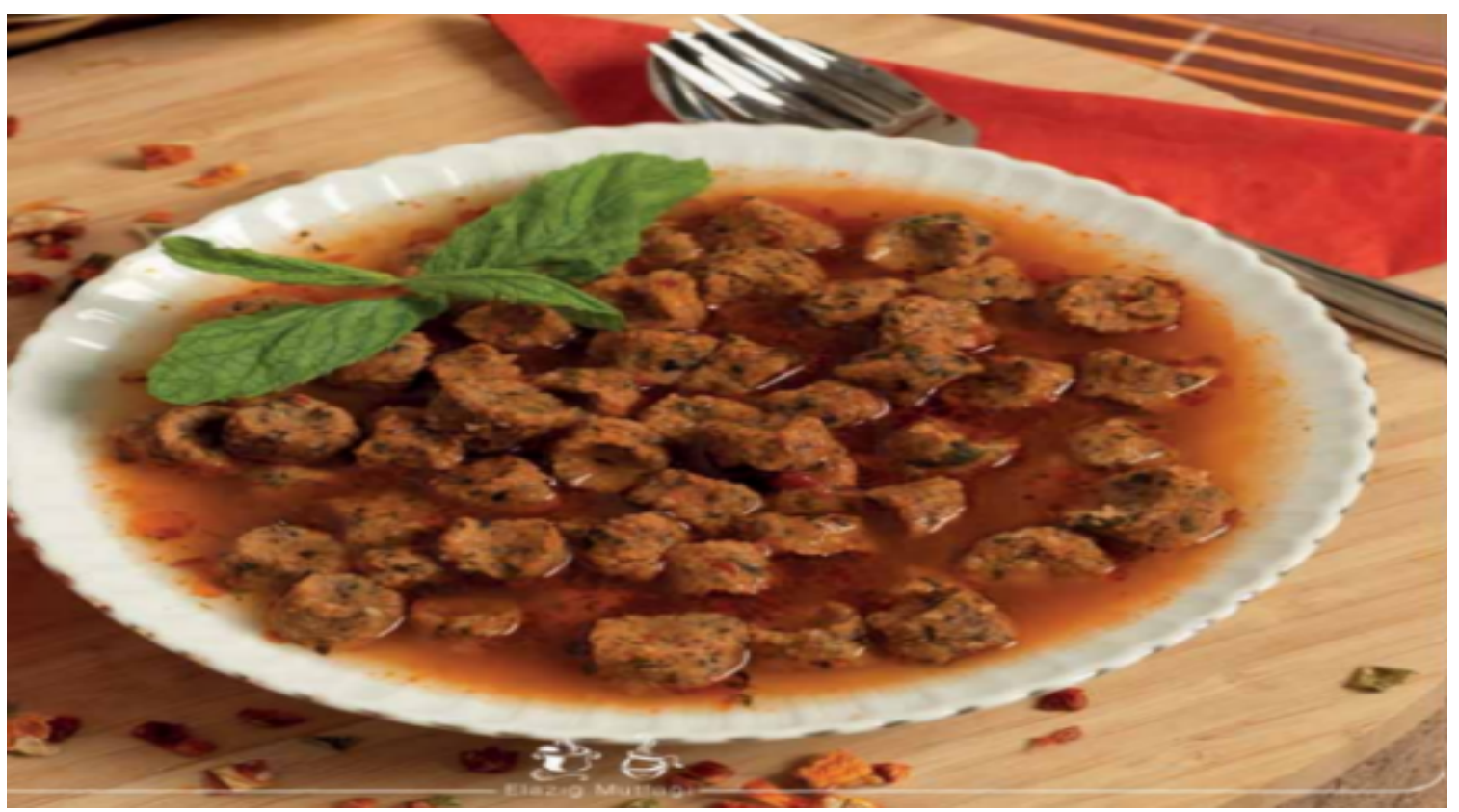

Resim.3 Harput Köfte

Kaynak: (www.elazig.ktb.gov.tr)

\section{Malzemeler:}

Yağsız Kıyma, Köftelik Bulgur, Dövme Yarma Bulgur, Kuru Soğan, Kuru Reyhan, Maydanoz, Domates Salçası, Biber Salçası, Su, Sıvıyă̆, Pul biber, Tuz

Yapılışı: Kuru soğan zırh veya bıçak yardımıyla çekilir. Üzerine yağsız kıyma, bulgur, biber ve domates salçası karışımı ve pul biber, reyhan, tuz ve doğranmış maydanoz ilave edilerek yoğrulur. Köfte hamuru kıvam aldıktan sonra misket büyüklüğünde yuvarlanarak ortasına bastırılır ve yaklaşık 1 saat dinlenmeye bırakılır. Bir tencerede ısıtılan sıvıyağ içerisinde geriye kalan salça karışımı kavrulur ve üzerine su ilave edilir. Su kaynadığında üzerine köfteler ilave edilerek yaklaşık 20 dakika pişirilir ve sıcak olarak servis edilir (www.elazig.ktb.gov.tr). 


\section{Kurutlu Gömme (Zarafat)}

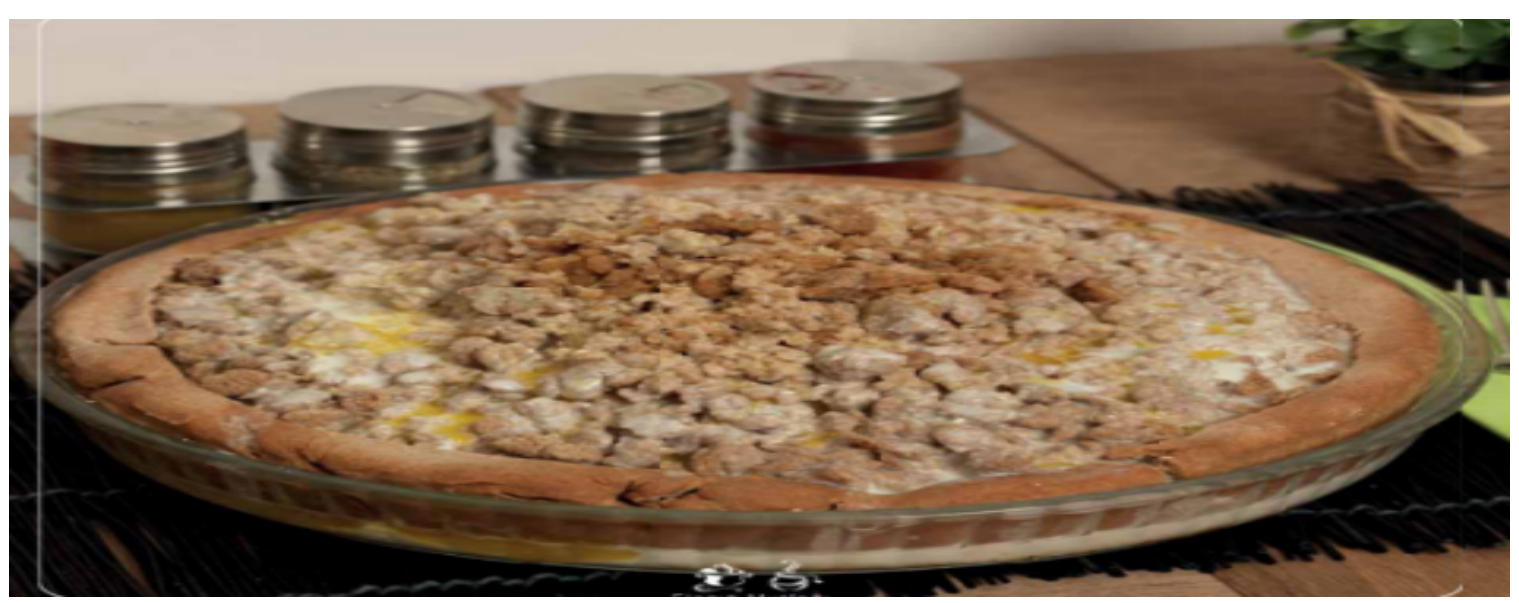

Resim 4. Zarafat

Kaynak: (www.elazig.ktb.gov.tr)

Malzemeler: Kurut ayranı, kepekli un, beyaz un, tereyağı, su, tuz

Yapılışı: Unlar elenir, su ve tuz eklenerek sert bir hamur yapılır. Hazırlanan hamur yağlanan tepsiye yayılır. Hamur, tepsiye yayıldıktan sonra kenarları içe doğru 2-3 cm parmakla hafifçe bastırılır. 180-200 derece 1sıtılmış fırında üst kısmı iyice kızarana kadar pişirilir. Piştikten sonra bıçak yardımıyla üst kısım kapak şeklinde çıkarılır. Pişen gömmenin iç kısmı soğumadan sıcak bir şekilde bıçak ile büyük parçalar halinde kesilir. Daha sonra kesilen parçalar elle ufalanır. Ufalanan parçalardan bir tepe oluşturulur. Üzerine hafif ısıtılmış kurut ayranı bir kaşık yardımı ile gezdirilir. Gömmenin tepe kısmına kurut ayranı dökülmez. İyice kızdırılmış tereyağı, kaşık yardımıyla ile kurut ayranı dökülen kısımların üzerine gezdirilir. Kızdırılmış tereyağının kalan kısmı, gömmenin tepe kısmına dökülür. Sıcak olarak servis edilir (elazig.ktb.gov.tr).

Tablo 4. Elazığ Mutfağında Yer Alan Hamur İşlerinin İsimlerine İlişkin Bulgular

\begin{tabular}{|l|l|}
\hline Çekme Ekmek & (Katılımc1 1,2,3,4,5,6,7,8,9,10,11,12,13) \\
\hline El böreği & (Katılımcı 1,2,5,7,8,10) \\
\hline Fetir Ekmek & (www.elazig.ktb.gov.tr) \\
\hline Fırın Tandır Ekmeği & (Katılımc1 1,2,3,4,5,6,7,8,9,10,11,12,13) \\
\hline Fodula Ekmeği & (Katılımc1 1,2,4,5,6,10,11,12,13) \\
\hline Katmer & (Katılımcı 11,12,13) \\
\hline Kuru Börek & (Katılımc1 1,8,12,13) \\
\hline Küncü Gömme & (Katılımc1 2,3,7,8,9,10,11) \\
\hline Peynirli Ekmek & (Katılımcı 1,2,3,4,5,6,7,8,9, 10,11,12,13) \\
\hline Pişi/Bişi & (www.elazig.ktb.gov.tr) \\
\hline Sac Ekmeği & (Katılımc1 1,2,3,4,5,6,7,8,9,10,11,12,13) \\
\hline Soğanlı Çökelekli Patila & (Katılımc1 1,2,3,4,5,6,7,8,9,10,11,12,13) \\
\hline Tandır (Top) Ekmeği & (Katılımc1 2,3,4,9,10,11,13) \\
\hline Yufka Ekmeği & (Katılımc1 1,2,3,4,5,6,7,8,9,10,11,12,13) \\
\hline Tırnaklı Pide & (Katılımc1 1,2,3,4,5,6,7,8,9,10,11,12,13) \\
\hline Yağlı Ekmek & (Katılımc1 1,2,3,4,5,6,7,8,9,10,11,12,13) \\
\hline
\end{tabular}


Elazığ mutfağında yer alan hamur işleri ekmek çeşitliliği ve ekmek hamurundan hazırlanan farklı yiyecek ürünleri bakımından zengindir. Katılımcılara Elazı̆̆ mutfak kültüründe yer alan çorbaların isimleri hakkında bilgi verir misiniz? sorusu yöneltilmiş alınan cevaplar Tablo 4 'de belirtilmiştir. Fetir ekmek ve pişi ile ilgili bilgiler "(www.elazig.ktb.gov.tr)" internet sitesinden yararlanılarak tabloya eklenmiştir.

Katılıcımlar ile gerçekleştirilen görüşmeler doğrultusunda tespit edilen 16 adet hamur işi Tablo 5'de belirtilmiştir. "Çekme ekmek, Fırın tandır ekmeği, Peynirli ekmek, Sac ekmeği, Soğanlı çökelekli patila, Yufka ekmeği, Tırnaklı pide ve Yağlı ekmek" katılımcılar çoğunluğu tarafından yanıt verilen hamur işleridir. Katmer, kuru börek, tandır(top) ekmeği ise diğer yiyecek ürünlerine kıyasla daha az katılımcı tarafından bilinmektedir.

Elazığ mutfağında yer alan yemeklerin genel içerikleri ile ilgili katılımcıların verdiği yanıtlar şu şekildedir:

"Ekmeklerimizi özellikle bahar ve yaz aylarında çevremizdeki yakınlarımızla birlikte evlerimizin bahçesinde veya köylerimizde odun ateşinde veya tüplü saclarda hazırlyyoruz. Kış aylarına hazırlık olması için yufkaları ince bir şekilde açıp tandır ekmekleri pişiriyoruz. Kış aylarında ise ticari firınlarda tırnaklı pide, çekme ekmek, patila, peynirli ekmek ve bazen tandır ekmeği hamuru hazırlayıp firınlarda hazırlatma imkânımız da oluyor. Şehrimizde bulunan ticari firılar yalnızca ekmek yaptırmak veya satın alma amacıyla kullanmıyoruz. Aynı zamanda evde hazırladığımız tepsi yemeklerini, güveçlerimizi, sebzelerimizi pişirebilmek için sürekli olarak kullanıyoruz" (Katılımcı 1,2,11,12,13).

"Ekmeklerde genellikle un, maya, su ve tuz kullanıyoruz. Ĕ̆er ekmeklerimiz uzun süre bekletilecekse içerisine maya eklemeden hazırliyoruz" (Katılımoı 1,3,11,12,13).

"Küncü gömme cenazesi olan ailelerin kendileri veya yakın eş ve dostlar tarafından hazırlanır. Genellikle hamurların kat kat açılarak içerisine soğan, tereyağı ve küncü (kavrulmuş susam ezmesi) ilave edilmesiyle taş firınlarda pişirilerek hazırlanır. Kuru börekte aslında hamurlar ince bir şekilde açıldıktan sonra arasına tuzsuz peynir ve maydanoz ilave ederek firında pişirip kahvaltılarımızda tüketiyoruz. Katmeri de börek olarak sabah tüplü sac ocaklarında hamuru tandır ekmeği gibi açıp arasına peynir ve maydanoz ekleyip pişirerek üzerine tereyağı sürüp tüketiyoruz. Elbette kişiden kişiye içerisine ilave edilen malzemeler değişiklik gösterebiliyor" (Katılımcı 2,3,7,8,9,10,11).

\section{Katmer}

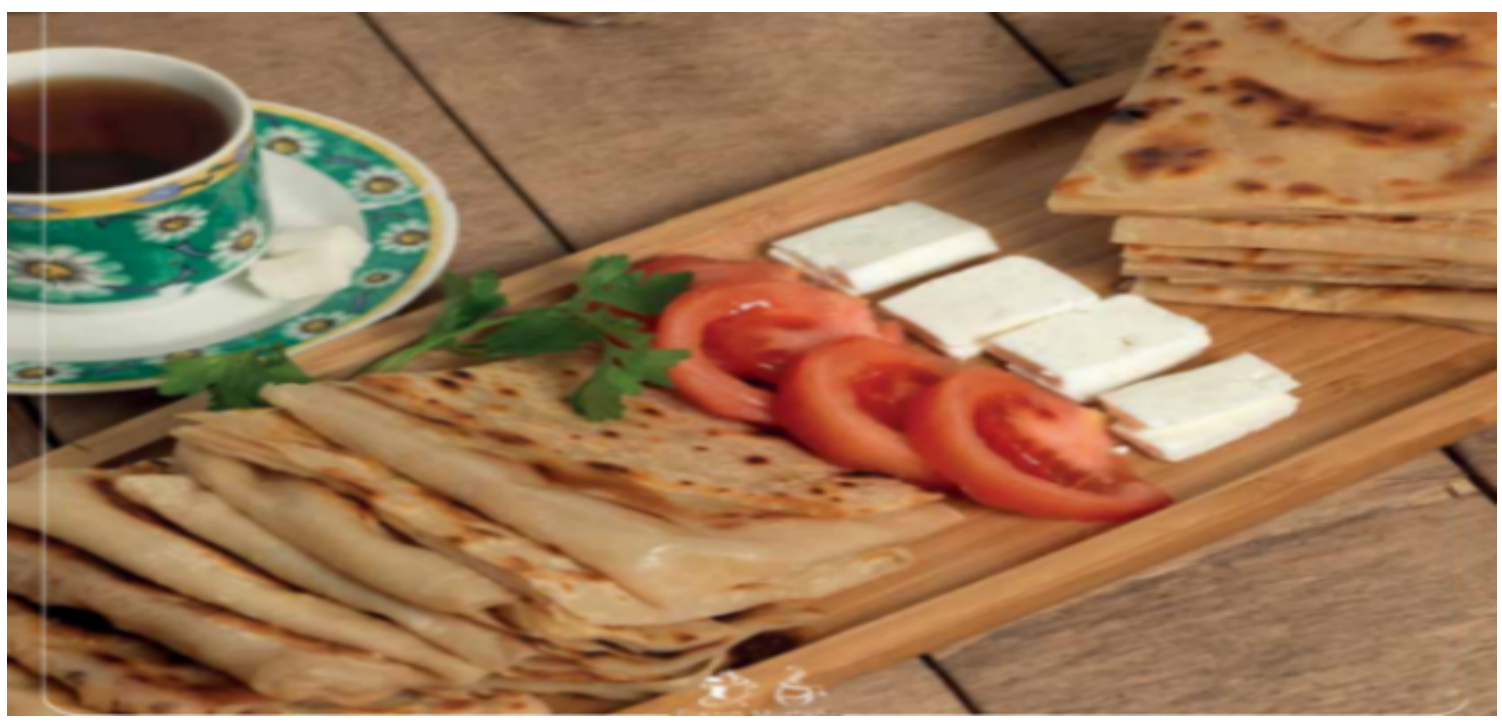

Resim.5 Katmer

Kaynak: (www.elazig.ktb.gov.tr) 
Malzemeler: Un, su, tuz Üzeri İçin: Tereyağ 1

Yapılışı: Bir yoğurma kabında un su, tuz ve biraz tuz ile yumuşak bir hamur yoğurulur. Hamurdan bezeler yapılarak bir yufka açılır. Açılan yufkanın üzerine eritilmiş tereyağı bir fırça ile sürülür. Yağlanmış yufka zarf şeklinde katlanır. Katlanan yufka tekrar açılır ve tekrar yağlanarak zarf şeklinde katlanır. Ekmek sacında veya tavada her iki tarafı kızarıncaya kadar pişirilir. Pişen katmerlere az miktarda eritilmiş tereyağ 1 sürülerek servis edilir (elazig.ktb.gov.tr).

Katılımclardan elde edilen yanıtlar sonucunda hamur işlerinin yöre mutfağ sahip olduğu çıkarımında bulunulması mümkündür. Genel olarak bu yiyecek ürünlerini köylerde veya evlerinin bahçelerinde taş tandırlar kurarak hazırladıklarını veya böyle bir imkâna sahip değillerse ürünün genel malzemelerini hazırlayıp ticari fırınlara pişirilmek üzere verdiklerini belirtmişlerdir. Buna ek olarak ticari fırınlarında mutfak kültüründe önemli bir yere sahip olduğu çıkarımında bulunulabilir. Hamur işlerinin hazırlanış biçimleri ile ilgili açıklamalarda katmer'in sabah kahvaltılarında tüketilmek üzere sac ocaklarda pişirilen bir yiyecek ürünü olduğu tespit edilmiştir. Bu durum Gaziantep mutfağında hamur tatlısı olarak hazırlanan katmer ile farklılık göstermektedir.

\section{Peynirli Ekmek}

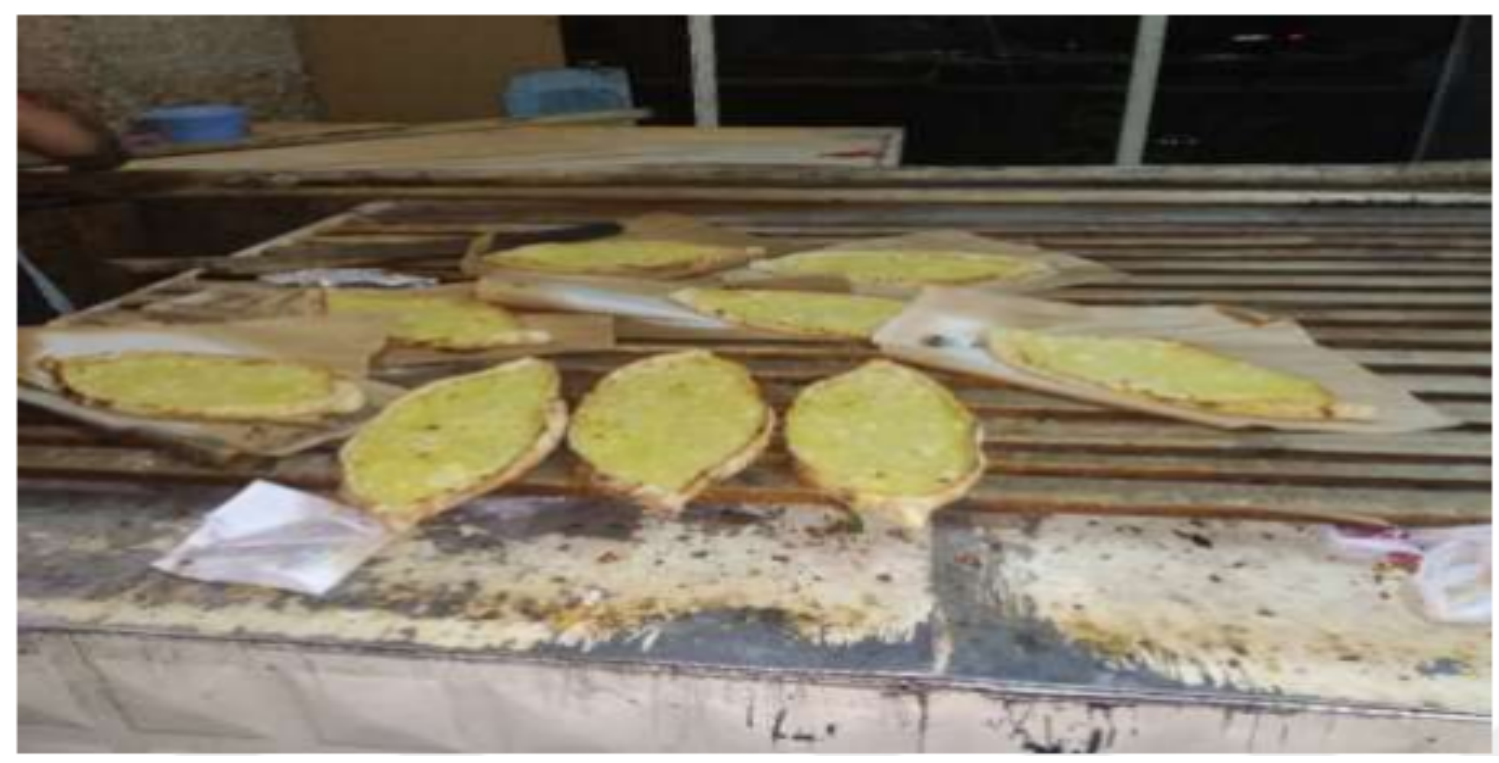

Resim.6 Peynirli Ekmek

Kaynak: Güleç, 2020

Malzemeler: Un, maya, su, tuz İç Harcı: Tuzsuz Peynir, Şeker

Yapılışı: Un, maya, su ve tuz bir kap içerisinde yoğurulur ve dinlendirilir. Peynir ve şeker bir tepsi içerisinde hamur kıvamına getirilir. Hamur açılır ve hazırlanan peynir harcı hamurun üzerine ilave edilir. Hamurun kenarları kıvrılır. Tercihen üzerine ceviz eklenir. Taş fırında meşe odunu ateşinde kızarana kadar pişirilmektedir (Güleç, 2020).

Elazığ mutfağında yer alan tatlı ve içecek türleri birlikte değerlendirilmiştir. Katılımcılara Elazı̆̆ mutfak kültüründe yer alan tatlı ve içeceklerin isimleri hakkında bilgi verir misiniz? sorusu yöneltilmiş alınan cevaplar Tablo 5 'de belirtilmiştir. 
Tablo 5. Elazı̆̆ Mutfağında Yer Alan Tatlı Ve İçeceklerin İsimlerine İlişkin Bulgular

\begin{tabular}{|l|l|}
\hline Dolanger & $($ Katılımcı 1,2,3,4,5,6,7,8,9,10,11,12,13) \\
\hline Halbur Hurması & (Katılımcı 12,13) \\
\hline Dilber Dudağı & (Katılımcı 1,2,8,9,11,12) \\
\hline Taş Ekmeği & (Katılımcı 1,3,11,12,13) \\
\hline Gaygana/Kaygana & (Katılımcı 5,6,9,10) \\
\hline Un Helvası & (Katılımcı 1,2,3,4,5,6,7,8,9,10,11,12,13) \\
\hline Tel Kadayıf & (Katılımcı 1,2,3,4,5,6,7,8,9,10,11,12,13) \\
\hline Koruk Şerbeti & (Katılımcı 11,12) \\
\hline Erik Hoşafı & (Katılımcı 3,8,13) \\
\hline Vişne Şurubu & (Katılımcı 1,2,3,4,5,6,7,8,9,10,11,12,13) \\
\hline Vişne Kompostosu & (Katılımc1 1,2,3,4,5,6,7,8,9,10,11,12,13) \\
\hline Çedene Kahvesi & (Katılımcı 1,2,3,4,5,6,7,8,9,10,11,12,13) \\
\hline
\end{tabular}

Katılıcımlar ile gerçekleştirilen görüşmeler doğrultusunda tespit edilen 9 farklı tatlı türü ve 3 adet içecek Tablo 5'de belirtilmiştir. "Dolanger, Un helvası, Tel kadayıf, Vişne kompostosu, Vişne şurubu ve Çedene kahvesi" en çok yanıt verilen tatlı ve içecek grubu arasındadır.

Elazığ mutfağında yer alan tatlı ve içeceklerin genel içerikleri ile ilgili katılımcıların verdiği yanitlar şu şekildedir:

"Yaptı̆̆ımız tatlılar çoğunlukla evlerde hazırlanıyor" (Katılımcı 1,3,4,6,7,8,9,10,11,12).

"Tatlılar için genellikle hamur hazırlayıp pişirdikten sonra üzerine şerbet dökerek yapıyoruz" (Katılımc1 $4,8,12,13)$.

"Un helvasinı özellikle cenazelerin ilk günlerinde taziyeye gelen misafirlere ikram ediyoruz. Bu helva genelde un kavurduktan sonra üzerine süt şerbeti veya su ile şurup hazırlanı üzerine dökülerek pişiriliyor" (Katılımcı 2,13).

"Bayramlardan önce hazırlıklarımız çok yoğun olur. Kapalı çarşıdaki el yapımı kadayıf satan dükkânlardan bunu ham bir şekilde satın alıp içerisine genelde ceviz ekleyip evlerde kendimiz pişiriyoruz" (Katılımol, $5,9)$.

"Çedene kahvesi sürekli olarak tükettiğimiz içeceklerden birisidir. Eskiden çedeneyi büyük taş havanlarda döverek köylerimizde kendimiz hazırlardık. Ama şimdi dışarıdan hazır olarak süt veya su ile hazırlayıp tüketiyoruz"(Katılımcı 10).

"Vişneleri genellikle yaz ayından toplayıp veya tezgâhlardan satın alıp derin dondurucuda saklarız. Yaz ayında sıklıkla tükettiğimiz zamanlarda oluyor. Ancak kış aylarında dondurucularda sakladığımız vişneleri çıkarıp kompostosunu veya şurubunu yapıyoruz" (Katılımcl, 12).

Katılımclar tatlıların genel olarak şerbetli olduğundan bahsetmektedir. Bahsedilen tatlıların özellikle hamur tatlısı olduğu anlaşılmaktadır. Hazır olarak yalnızca kadayıfın ham bir şekilde satın alındığına dair bilgiler mevcuttur. İçecekler içerisinde yalnızca çedene kahvesinin hazır olarak tüketildiği ve eski zamanlarda çedenenin taş havanlar içerisinde dövülerek hazırlandığına dair sonuçlara ulaşılmıştır. 


\section{Dolanger}

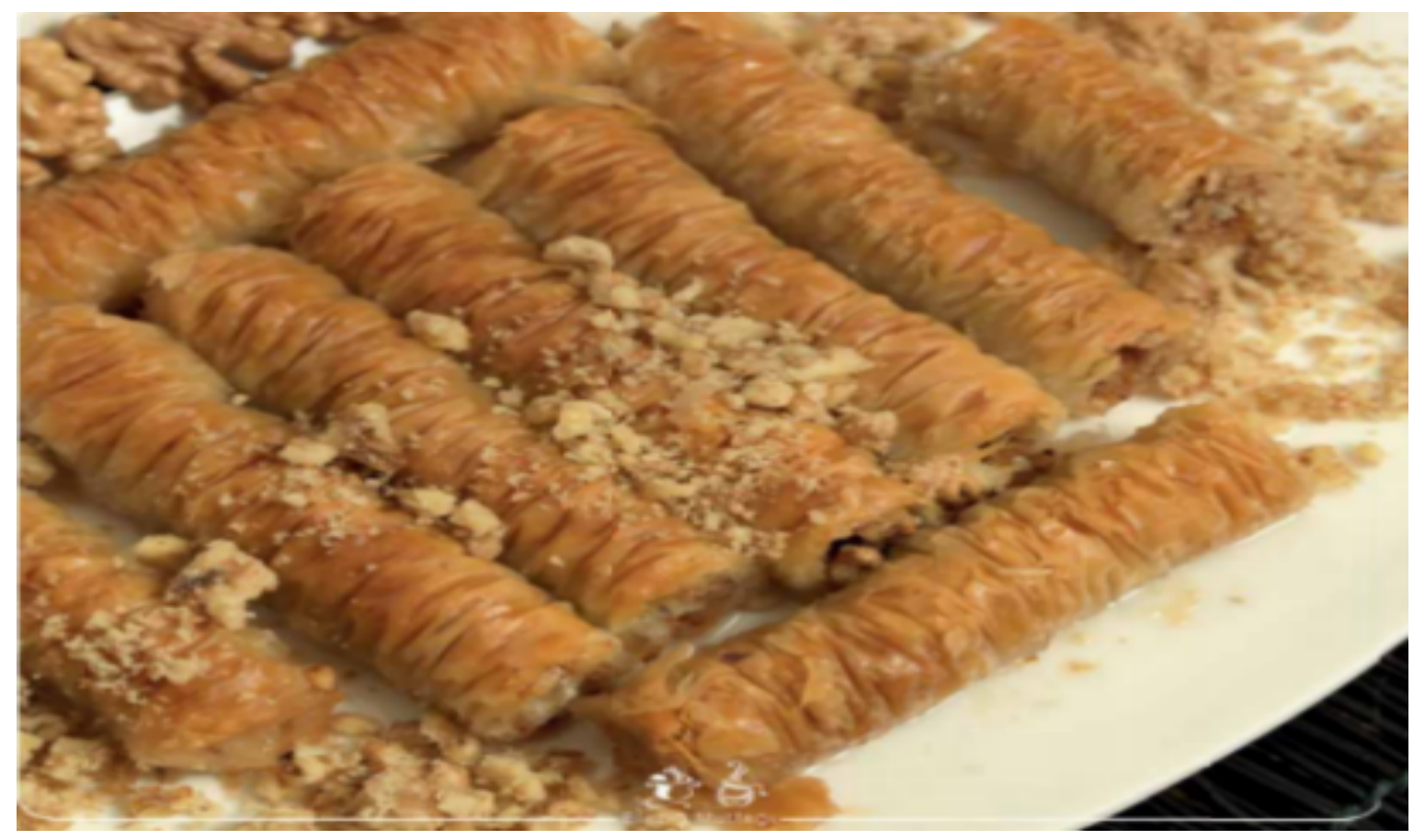

Resim.7 Dolanger

Kaynak: (elazig.ktb.gov.tr)

Malzemeler: Hamuru için; baklavalık un, yoğurt, süt, yumurta, zeytinyağı, kabartma tozu, sirke, tuz, İç Malzemeler; cevizi içi, buğday nişastası, tereyağı Şerbeti için; şeker, su, limon tuzu

Yapılışı: Bir yoğurma kabına yumurtalar kırılır, bir fiske tuz ilave edilerek karıştırılır. Yumurtanın üzerine yoğurt, süt, zeytinyağı ve sirke ilave edilerek karıştırılır. Bu karışımın üzerine un ve kabartma tozu eklenir. Yumuşak bir hamur elde edinceye kadar yaklaşık 6-8 dakika yoğurulur. Hamurun üzeri 1slak bir bezle örtülerek 30 dakika dinlendirilir. Şerbeti için; bir tencerede su ve şeker karıştırılarak kaynamaya bırakılır. Yaklaşık 15 dakika daha kaynatılarak şerbet hazır hale getirilir. Ocaktan alınmadan 1-2 dakika önce limon tuzu ilave edilir. Daha sonra cevizler havanda dövülür. Hamurlar beze haline getirildikten sonra nişasta serpilerek baklava yufkası gibi açılır. Açılan yufka ortadan ikiye bölünür. Bölünen yufkanın oval kısmından başlanarak yarısına kadar ceviz içi serpilir. Yufkaları oklavaya dolarken yarısına ceviz konulmaz. Yufka, ceviz serilen oval tarafından başlanarak oklavaya sarılır. Sarılan yufka her iki ucundan tutularak ortaya doğru büzüştürülür. Oklava, büzüştürülen yufkanın içinden çekilerek çıkartılır ve yağlanmış tepsiye dizilir. Tepsi doluncaya kadar her yufka için aynı işlem uygulanır. Tepsi dolunca, eritilmiş tereyağ fırında kızartılır. Fırından çıkarıldıktan 2-3 dakika sonra dolangerlerin üzerine 1 lık şerbet dökülür. Yaklaşık 3-4 saat dinlendirildikten sonra servis edilir (www.elazig.ktb.gov.tr). 


\section{Vişne Şurubu}

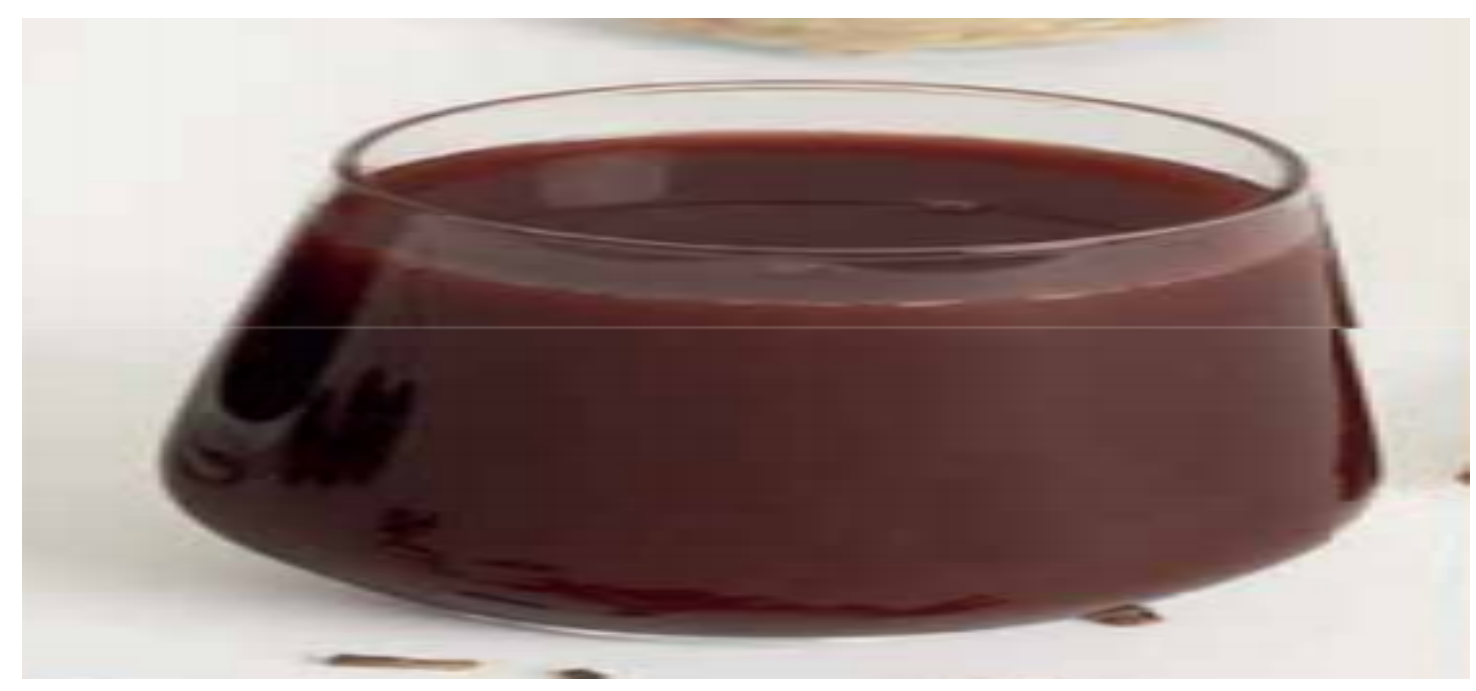

Resim. 8 Vişne Şurubu

Kaynak: (www.elazig.ktb.gov.tr)

Malzemeler: Vişne Şurubu için: vişne konsantresi, soğuk su vişne Konsantresi için: vişne, şeker, limon tuzu, su.

Vişne Şurubunun Yapılışı: Bir bardak soğuk suya 1-2 yemek kaşığı vişne konsantresi karıştırılarak hazırlanır.

Vişne Konsantresinin Yapılışı: Vişneler saplarından ayrılarak yıkanır. Bin tencereye vişneler konur. Üzerine bir miktar su eklenir ve kaynatılır. Vişneler yumuşayınca tencere ocaktan alınır. Başka bir kapta kevgir ile süzülür. Kevgir üzerinde kalan vişneler de biraz sıkılır. Süzdürülen vişne suyu başka bir tencereye alınır. Şeker ilave edilerek karıştırılır. Kaynama esnasında üzerindeki köpükler alınır. Vişne suyunun üçte biri kalıncaya kadar kaynatılır. Ocaktan alınmadan önce limon tuzu ilave edilir. Ocaktan alınan vişne konsantresi soğutulur. Kavanozlara doldurularak saklanır (www.elazig.ktb.gov.tr).

\section{SONUÇ ve TARTIŞMA}

Geçmişten günümüze farklı medeniyetlere ev sahipliği yapmış Türkiye'nin yemek kültürü oldukça zengindir. Türkiye bulunduğu coğrafi konum ve farklı yaşam tarzları ve kültürlerin etkisiyle iller bazında değerlendirildiğinde zengin bir yemek çeşitliliğine sahiptir (Çuhadar, Küçükyaman ve Şaşmaz, 2018). Bu noktada yörelere göre bölgelerin veya illerin sahip olduğu mutfak unsurların kapsayan yöresel mutfak kavramının varlığından söz etmek mümkündür. Yöresel mutfak, yöresel yiyecek/ yöresel gıda ve yöresel yemekleri içerisine alan geniş bir kavramdır (Erdem, Mızrak ve Kemer, 2018) Bu kavram bir coğrafi yörenin kültürünü yansıtan, yöreye ait yemek hazırlama yöntemleri ve ekipmanları ile hazırlanan ve yöre halkı için anlam taşıyan yiyecek ve içecekler olarak ifade edilmektedir (Şimşek, Türkmendağ ve Türkmendağ, 2017). Yöresel yiyecekler o yörede yaşayanlar için önem taşımasının yanı sıra turizm ürününü geliştiren ve turistler için bir pazar oluşumunu sağlayan unsurlardır (Boyne, Hall ve Williams, 2003:134). 
Yapılan çalışmalar yöresel yemeklerin destinasyonlar adına önemli bir çekicilik unsuru olduğunu desteklemektedir (Özdemir, 2007; Güneş, 2008; Hacıoğlu vd., 2009; Çevik ve Saçlık, 2011; Soner, 2013; Altunsaban vd., 2017). Yöresel yemeklerin gastronomi turizmi açısından önemli olduğu düşünüldüğünde bu çalışmada Elazığ ilinin yöresel yemekleri değerlendirilmiştir. Elde edilen bulgular neticesinde Elazı ̆ mutfak kültüründe yer alan 43 yemek, 12 çorba, 16 hamur işi, 12 tatlı ve içecek türü tespit edilmiştir. Yemekler içerisinde erişte pilavı, etli yaprak sarması, güveç, Harput köfte, içli köfte, kara kavurma, mercimek köftesi, mukaşerli bulgur pilavı, patates kavurması, dilim dolma, pirpirim (semizotu) yemeği, sırın, söğürtme, yoğurtlu ıspanak kavurması, zeytinyağlı/ etli nahna (lahana) sarması, zeytinyağlı/etli kofik dolmasının en fazla yanıt verilen yemekler olduğu sonucuna ulaşılmıştır. Çorbalar kategorisinde tarhana çorbasının, hamur işlerinden çekme ekmek, fırın tandır ekmeği, sac ekmeği, soğanlı çökelekli patila, yufka ekmeği, tırnaklı pide, yağlı ekmeğin ve son olarak tatlı ve içecek kategorisinde dolanger, un helvası, vişne şurubu, vişne kompostosu ve çedene kahvesinin bilinirliği en fazla olan yöresel yiyecek ve içecek ürünleri olduğu tespit edilmiştir.

Elazığ yöresel mutfağında yer alan yemek ve çorbaların içeriği çoğunlukla tahıl ve hayvansal ürünlerden oluşmaktadır. Sebze yemekleri dâhil olmak üzere bazı kesimlerde bu ürünlerin içerisine et ilave edilerek tüketildiğine rastlanmaktadır. Tatlıların çoğunluğu şerbetli tatlı kategorisinde yer almaktadır. İçeceklerin büyük bir kısmının taze meyveler ile doğal yöntemler ile hazırlanan şuruplar olduğu görülmektedir. Bahsedilen yiyecek ve içeceklerin dışında bastuğ (pestil), orcik, dut unu, eşbabiye (kayısı kurusu), ağın leblebisi gibi ürünlerinde yaygın olarak tüketildiği ifade edilmektedir (Katılımcı 1,12,13).

Bir yörenin mutfak kültürünün zengin olması, o yöreyi ziyaret eden turistlerin tekrar ziyaret etme niyetlerini pozitif yönde etkilediği (Zağralı ve Akbaba, 2015) düşünüldügünde kendine has zengin bir mutfak yapısıyla Elazığ yöresel yemeklerinin yöreyi ziyaret eden turistler üzerinde bu şekilde bir etki yaratacağı düşünülmektedir. Katılımcılar ve ikincil kaynaklardan elde edilen bilgiler ışığında Elazığ ilinin gastronomi turizmi açısından potansiyelinin olduğu ancak etkin bir şekilde kullanılmadığına dair kanıtlar bulunmaktadır. Güleç (2020)'in "Elazığ Gastronomik Kimliğinin Destinasyon İmajı Açısından Değerlendirilmesi" isimli tez çalışmasında yerli turistlerin Elazığ gastronomik kimliğinin şehrin imajını olumlu yönde etkilediğini ve Elazı̆̆ yemeklerini genel olarak beğendikleri sonucuna ulaşılmıştır. Aynı çalışmadan hareketle Elazığ 'ın yöresel yemekleri turistleri tatmin edebilecek çeşitliliğe sahip olsa da bu ürünlerin arzını sağlayacak restoran işletmelerinin sayısının ve tanıtım faaliyetlerinin yetersiz olduğu anlaşılmaktadır. Elde edilen bulgular neticesinde şehirdeki yöresel ürünleri ön plana çıkaracak farklı bir olumsuz gelişme ise yabancı mutfaklara ait restoran sayısının son yıllarda artış göstermesidir. Bu durum yöresel ürünlerin pazarlanmasını olumsuz yönde etkilemesinin yanı sıra sürdürülebilirliği açısından da risk oluşturmaktadır.

Araştırma bulguları ve ilgili alanyazın taraması neticesinde bölgeye özgü yöresel yemeklerin tanıtımına ve sürdürülebilirliğine yönelik aşağıda verilen öneriler geliştirilmiştir:

- Elazığ yöresel ürünlerinin tanıtımına katkı sağlaması açısından düzenlenen yemek festivallerinin sayıları arttırılabilir.

- Sektörün önde gelen şefleri davet edilerek sosyal medyanın günümüzdeki etkisi kullanılarak yöresel yemek yarışmaları düzenlenebilir.

- Yemeklerin turistlere yönelik tanıtımı hususunda otel ve restoran yöneticileri bilgilendirilerek şehrin tanıtımını yapan el kitapçıklarında yöresel yemeklere ait bilgilere de yer verilebilir.

- Yiyecek-içecek işletmelerine yönelik eğitimler düzenlenerek konunun önemi hakkında duyarlılık eğitim etkinlikleri düzenlenebilir. 
- Yöresel yemeklerin sürdürülebirliğinin sağlanması açısından şehirde ki ilgili bölümlerin üniversite ve lise müfredatlarında Elazı̆̆ mutfak kültürüne yönelik seçmeli dersler eklenebilir.

$\mathrm{Bu}$ çalışmanın bazı sınırlılıkları bulunmaktadır. Araştırmada nitel araştırma yöntemleri kapsamında görüşme tekniği ve ikincil veri kaynakları kullanılmıştır. Araştırma kapsamında Elazığ ilinde ikamet eden belirli bir gruptaki ev hanımı ile görüşülmüştür. Bir sonraki çalışmalar da otel ve restoran menülerinde yöresel yiyeceklere yer verilme durumunun tespit edilmesine yönelik ilgili konunun tekrar ele alınması mümkündür.

\section{KAYNAKÇA}

Aksoy, M., ve Sezgi, G. (2015). Gastronomi Turizmi ve Güneydoğu Anadolu Bölgesi Gastronomik Unsurları. Journal of Tourism and Gastronomy Studies, 3(3), 79-89.

Aydoğdu, A., ve Duman, S. (2017). Destinasyon Çekicilik Olarak Gastronomi Turizmi: Kastamonu Örneği. Turizm ve Araştırma Dergisi, 6(1), 4-23.

Aydoğdu, A., Özkaya-Okay, E., ve Köse, Z. (2006). Destinasyon Tercihinde Gastronomi Turizmi'nin Önemi: Bozcaada Örneği. Uluslararası Türk Dünyası Turizm Araştırmaları Dergisi, 1(2), $4-23$.

Altunbasan, S., Yay, Ö., ve Erdem, Ö. (2017). Yöresel Mutfak Kavramına İlişkin Şeflerin Bakış Açılarının Değerlendirilmesi, II. Rize Turizm Sempozyumu, Rize, Türkiye, 4-6 Kasım 2016, ss. 237-261.

Baltacı, A. (2018). Nitel Araştırmalarda Örnekleme Yöntemleri ve Örnek Hacmi Sorunsalı Üzerine Kavramsal Bir İnceleme. Bitlis Eren Üniversitesi Sosyal Bilimler Enstitüsü Dergisi, 7(1), 231274.

Başaran, B. (2017). Gastronomi Turizmi Kapsaminda Rize Yöresel Lezzetlerinin Değerlendirilmesi. Journal of Tourism and Gastronomy Studies, 5(3), 135-149.

Birdir, K., ve Akgöl, Y. (2015). Gastronomi Turizmi ve Türkiye'yi Ziyaret Eden Yabancı Turistlerin Gastronomi Deneyimlerinin Değerlendirilmesi. Işsletme ve İktisat Çalışmaları Dergisi, $3(2), 57-68$.

Boyne, S., Hall, D., and Williams, F. (2003). Policy, support and promotion for food-related tourism initiatives: A marketing approach to regional development. Journal of Travel $\mathcal{E}$ Tourism Marketing, 14(3-4), 131-154.

Chaney, S., and Ryan, C. (2012). Analyzing the evolution of Singapore's World Gourmet Summit: An example of gastronomic tourism. International Journal of Hospitality Management, 31(2), 309318.

Cohen, E., and Avieli, N. (2004). Food in Tourism: Attraction and Impediment. Annals of Tourism Research, 31(4), 755-778.

Cömert, M. (2014). Turizm Pazarlamasında Yöresel Mutfakların Önemi ve Hatay Mutfağ 1 Örneği. Journal of Tourism and Gastronomy Studies, 2(1), 64-70.

Çatır, O., ve Ay, E. (2018). Ulubey (Uşak) Yöresel Yemeklerinin Gastronomi Turizmi Açısından Değerlendirilmesi. Journal of Tourism and Gastronomy Studies, 6(2), 3-19. 
Çelik, S. (2018). Şırnak İlinin Gastronomi Turizm Potansiyeli. International Journal of Contemporary Tourism Research, 2(2), 41-51.

Çevik, S., ve Saçllı, M. (2011). Destinasyonun Rekabet Avantajı Elde Etmesinde Gastronomi Turizminin Rolü: Erdek Örneği. Düzce: 12. Ulusal Turizm Kongresi, 30 Kasım-4 Aralık.

Çuhadar, M., Küçükyaman, M., ve Şaşmaz, M. (2018). Geçmişten Günümüze Isparta Mutfak Kültürü: Nitel Bir Araştırma. Journal of Tourism and Gastronomy Studies, 6(3), 125-142.

Deveci, B., Türkmen, S., ve Avcıkurt, C. (2013). Kırsal Turizm İle Gastronomi Turizmi İlişkisi: Bigadiç Örneği. International Journal of Social and Economic Sciences, 3(2), 29-34.

Dilsiz, B. (2010). Türkiye'de Gastronomi ve Turizm İstanbul Örneği, İstanbul Üniversitesi Sosyal Bilimler Enstitüsü Turizm İşletmeciliği Anabilim Dalı, İstanbul.

Enright, M., and Newton, J. (2005). Determinants of Tourism Destination Competitiveness in Asia Pasific: Comprehensiveness and Universality. Journal of Travel Research, 43, 339-350.

Erdem, Ö., Mızrak, M., ve Kemer, A. (2018). Yöresel Yemeklerin Bölge Restoranlarında Kullanılma Durumu: Mengen Örneği. Uluslararası Türk Dünyası Turizm Araştırmaları Dergisi, 3(1), 44-61.

Everett, S., and Aitchison, C. (2008). The Role of Food Tourism in Sustaining Regional Identity: A Case Study of Cornwall, South West England. Journal of Sustainable Tourism, 16(2), 150-167.

Gillespie, C., and Cousins, J. (2001). European Gastronomy into the 21st Century. London: Oxford: Butterworth-Heinemann.

Gross, M., Brien, C., and Brown, G. (2008). Examining The Dimensions Of a Lifestyle Tourism Destination. International Journal of Culture, Tourism and Hospitality Research, 2(1), 44-66.

Güleç, E. (2020). Elazığ Gastronomik Kimliğinin Destinasyon İmajı Açısından Değerlendirilmesi. Yüksek Lisans Tezi, Ankara Hacı Bayram Veli Üniversitesi, Lisansüstü Eğitim Enstitüsü, Gastronomi ve Mutfak Sanatları Anabilim Dal, Ankara.

Güneş, G., Ülker, H., ve Karakoç, G. (2008). Sürdürülebilir Turizmde Yöresel Yemek Kültürünün Önemi. 1.Ulusal Gastronomi Sempozyumu ve Sanatsal Etkinlikler, 10-11 Nisan 2008. Divan Otel Tayla-Antalya.

Günlü, E., ve Şahin, N. (2007). Turizmde Ürün Geliştirme ve Alternatif Turizm. O. İçöz içinde, Genel Turizm (s. 141-166) Ankara:Turhan Kitabevi.

Güzel, M., ve Önçel, S. (2018). Destinasyonların Çekicilik Unsuru Olmasında Gastronomi Turizminin Rolü: Hatay Mutfak Kültürü Üzerine Bir Araştırma. International Gastronomy Tourism Studies Congress- (s. 64-78). Kocaeli: Kocaeli University.

Güzel-Şahin, G., ve Ünver, G. (2015). Destinasyon Pazarlama Aracı Olarak Gastronomi Turizmi: İstanbul'un Gastronomi Turizmi Potansiyeli Üzerine Bir Araştırma. Journal of Tourism and Gastronomy Studies, 3(2), 63-73.

Hacıoğlu, N., Girgin, G., ve Giritlioğlu, İ. (2009). Yiyecek-İçecek İşletmelerinin Pazarlama Faaliyetlerinde Yöresel Mutfakların Kullanımı: Balıkesir Örneği. 3. Ulusal Gastronomi Sempozyumu Bildirileri, 17-18 Nisan 2009. Antalya: Akdeniz Üniversitesi Alanya İşletme Fakültesi. Antalya 
Hall, M., Mitchell, R., and Sharples, L. (2003). Consuming places: the role of food, wine and tourism in regional development. M. Hall, L. Sharples, R. Mitchell, N. Macionis, and B. Cambourne içinde, Food Tourism Around the World. Burlington Elsevier Butterworth-Heinemann.

Hamamcıbaşı, F. (2006). Yiyecek Turizmi ve Yiyecek Turizmini Açısından Bozcaada'nın Kaynakları, Çanakkale Onsekiz Mart Üniversitesi, Sosyal Bilimler Enstitüsü, Turizm İşletmeciliği Anabilim Dalı, Çanakkale.

Hu, Y., and Ritchie, J. B. (1993). Measuring destination attractiveness: A contextual approach. Journal of Travel Research, 32(2), 25-34.

http://www.elazig.gov.tr/elazig-harput-mutfagi---yoresel-yemekler [Erişim Tarihi: 20.12.2020]

https://data.tuik.gov.tr/Bulten/Index?p=Adrese-Dayali-Nufus-Kayit-Sistemi-Sonuclari-201933705 [Erişim Tarihi: 18.12.2020]

https://elazig.ktb.gov.tr/Tr-187422/Elazig-Harput-Mutfagi.Html [Erişim Tarihi: 20.12.2020]

https://elazig.ktb.gov.tr/TR-246156/elazig-mutfagi.html [Erişim Tarihi: 25.12.2020]

https://www.kulturportali.gov.tr/portal/elazig-dan-12-ozel-lezzet [Erişim Tarihi: 21.12.2020]

https://sozluk.gov.tr/ [Erişim Tarihi: 18.12.2020]

https://www.turkiye-rehberi.net/ [Erişim Tarihi: 19.12.2020]

https://commons.wikimedia.org/wiki/Main_Page [Erişim Tarihi: 18.12.2020]

İlban, M., ve Yıldız, N. (2020). Destinasyona Yönelik Müşteri Sadakati Oluşturmada Yöresel Mutfak Memnuniyeti ve Tüketici Güveninin Rolü: Sakarya/Adapazarı (Türkmen Mutfağı) Örneği. Güncel Turizm Araştırmaları Dergisi, 4(2), 240-260.

Kabasakal, U. (1993). Bölgelerarası dengeli kalkınma bakımından turizm ve Elâzı̆̆ örneği. (Yayımlanmamış Yüksek Lisans Tezi). İstanbul: Yeditepe Sosyal Bilimler Enstitüsü, İstanbul.

Karim, S. A. (2006). Culinary tourism as a destination attraction: An empirical examination of the destination's food image and information sources. Unpublished doctoral dissertation Oklahoma State University, Oklahoma.

Kivela, J., and Crotts, J. (2005). Gastronomy tourism: a meaningful travel market segment. Journal of Culinary Science and Technology, 4(2-3), 39-55.

Kivela, J., and Crotts, J. (2006). Tourism and Gastronomy: Gastronomy's Influence on How Tourists Experience a Destination. Journal of Hospitality and Tourism Research, 30(3), 354-377.

Lee, I., and Arcodia, C. (2011). The Role of Regional Food Festivals for Destination Branding. International Journal of Tourism Research, 13(4), 355-367.

Long, M. (2010). Culinary Tourism, USA: The University Press of Kentucky.

Lordkipanidze, M., Brezet, H., and Backman, M. (2005). The Entrepreneurship Factor in Sustainable Tourism Development. Journal of Cleaner, 13(8), 787-798.

Okumuş, B., Okumuş, F., and McKercher, B. (2007). Incorporating Local and International Cuisines in the Marketing of Tourism Destinations: The Cases of Hong Kong and Turkey. Tourism Management, 28(1), 253-261. 
Ölmez, Z. (2017). Balıkesir Üniversitesi Sosyal Bilimler Enstitüsü Turizm İşletmeciliği Anabilim Dalı Gastronomi Turizminde Yerli Ziyaretçilerin Yöresel Yiyeceklere Yönelik Unutulmaz Deneyimlerinin Davranışsal Niyetleri Üzerine Etkisi: Seferihisar Örneği. Yüksek Lisans Tezi, Balıkesir Üniversitesi, Sosyal Bilimler Enstitüsü, Turizm Otel İşletmeciliği Anabilim Dalı. Balıkesir.

Özdemir, G. (2007). Destinasyon Yönetimi ve Pazarlama Temelleri İzmir İçin Bir Destinasyon Model Önerisi. Doktora Tezi, Dokuz Eylül Üniversitesi Sosyal Bilimler Enstitüsü Turizm İşletmeciliği Anabilim Dalı, İzmir.

Özleyen, E., ve Tepeci, M. (2017). Manisa'da Yöresel Yemeklerin ve Lezzetlerin Turizmin Gelişimine Katkısının Belirlenmesi. Turizm Akdemik Dergisi, 4(2), 139-152.

Plummer, R., Telfer, D., Hashimoto, A., and Summers, R. (2005). Beer tourism in Canada Along the Waterloo-Wellington Ale Trail. Tourism Management, 26(3), 447-458.

Polat, M. (2020). Yöresel Yemek İmajının Destinasyon Tercihine Etkisi: Kahramanmaraş Örneği. Doğu Coğrafya Dergisi, 25(43), 183-194.

Renko, S., Renko, N., and Polonijo, T. (2010). Understanding the role of food in rural tourism development in a recovering economy. Journal of Food Products Marketing, 16(3), 309-324.

Richards, G. (2002). Gastronomy: An Essential Ingredient in Tourism Production and Consumption. A. Hjalager, and G. Richards içinde, Tourism and Gastronomy (s. 3-20). London: Routledge.

Soner, F. (2013). Gastronomy Tourism: A Solution For Small Cities Marketing And Regional Development (Yayımlanmamış Yüksek Lisans Tezi). İstanbul: Yeditepe Üniversitesi Sosyal Bilimler Enstitüsü.

Şeker, İ., ve Hastaoğlu, E. (2020). Gastronomi Turizmi Kapsamında Sivas Yöresel Yemeklerinin Mikro ve Makro Besin Öğelerinin İncelenmesi. Atatürk Üniversitesi Sosyal Bilimler Enstitüsü Dergisi, 24(4), 1879-1894.

Şengül, S., ve Genç, K. (2016). Festival Turizmi Kapsamında Yöresel Mutfak Kültürünün Destekleyici Ürün Olarak Kullanılması: Mudurnu İpekyolu Kültür Sanat ve Turizm Festivali Örneği. Pamukkale Üniversitesi Sosyal Bilimler Enstitüsü Dergisi, 23, 79-89.

Şengül, S., ve Türkay, O. (2016). Akdeniz Mutfak Kültürünün Gastronomi Turizmi Bağlamında Değerlendirilmesi. Journal of Tourism and Gastronomy Studies, 4(1), 86-99.

Şimşek, A., ve Güleç, E. (2020). Gastronomi Turizmi Kapsamında Coğrafi İşaretli Ürün: Elazı̆̆ Orciği. Aydın Gastronomy, 4(2), 73-81.

Şimşek, A., Türkmendağ, T., ve Türkmendağ, Z. (2017). Unutulmaya Yüz Tutmuş Yöresel Yemeklerin Turizm Potansiyeli Sağlamadaki Önemi: Sivas İli Örneği. Internatonal Congress On Cultural Heritage and Tourism(ICCHT). 3-9 May 2017. Konya, Turkey. ss:737-749.

Tikkanen, I. (2007). Maslow's Hierarchy and Food Tourism in Finland: Five Cases. British Food Journal, 109(9), 721-734.

Torun, C. (2015). Elazı ̆̆ İlinin Kırsal Turizm Potansiyelinin Belirlenmesine Yönelik Bir Çalışma. Yüksek Lisans Tezi, Balıkesir Üniversitesi, Sosyal Bilimler Enstitüsü, Turizm İşletmeciliği ve Otelcilik Anabilim Dalı, Balıkesir. 
Turan, B., ve Akoğul, E. (2019). Gastronomi Turizmine Arz Kaynağı Olabilecek Ürünlerin Belirlenmesi: Erzurum Mutfağı Örneği. Akademik Sosyal Araştırmalar Dergisi, 7(92), 370-384.

Tuna, M., ve Özyurt, B. (2018). Ankara'da Gastronomi Turizminin Değerlendirilmesi: Nitel Bir Araştırma. Journal of Tourism and Gastronomy Studies, 6(3), 73-87.

Yüncü, H. (2010). Sürdürülebilir Turizm Açısından Gastronomi Turizmi ve Perşembe Yaylası. S. Şengel içinde, Yerel Değerlerce Yayla Turizmi (s. 28-34). Ankara: Detay Anatolia Akademik Yayıncilik.

Zağralı, E., ve Akbaba, A. (2015). Turistlerin Destinasyon Seçiminde Yöresel Yemeklerin Rolü: İzmir Yarımadası'nı Ziyaret Eden Turistlerin Görüşleri Üzerine Bir Araştırma. Journal of Yasar University, 10(40), 6633-6644.

Zengin, B., ve Işkın, M. (2017). Yerel Mutfakların Gastronomi Turizmi AçısındanDeğerlendirilmesi: Sivas Örneği. Akademik Sosyal Araştırmalar Dergisi, 5(40), 404-415. 